\title{
SUMMARY OF PROPOSED APPROACH FOR DERIVING CLEANUP GUIDELINES FOR RADIONUCLIDES IN SOIL AT BROOKHAVEN NATIONAL LABORATORY
}

\author{
A. F. Meinhold, S. C. Morris, B. Dionne, and P. D. Moskowitz
}

November 1996

"Radiological Sciences Division

Department of Advanced Technology

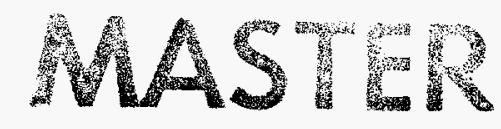

BIOMEDICAL AND ENVIRONMENTAL ASSESSMENT GROUP

ANALYTICAL SCIENCES DIVISION

DEPARTMENT OF APPLIED SCIENCE

BROOKHAVEN NATIONAL LABORATORY

ASSOCIATED UNIVERSITIES, INC.

Under Contract No. DE-AC02-76CH00016 with the

U. S. Department of Energy 


\section{CONTENTS}

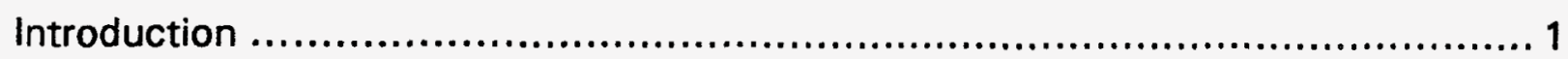

Brookhaven National Laboratory ................................................... 2

Hazardous Waste Management Facility (HWMF) ................................... 3

Other Radiologically Contaminated Soils ..........................................

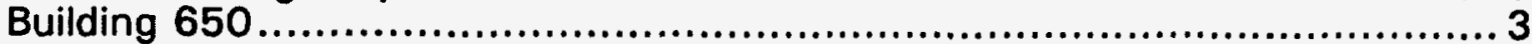

Dose Limit for Derivation of BNL Cleanup Guidelines .............................. 3

Restricted Use and Institutional Control ..............................................6

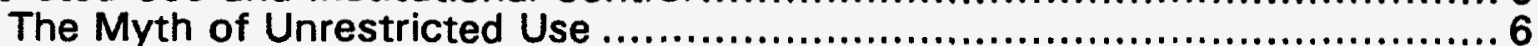

Restricted Use and Institutional Control ............................................ 6

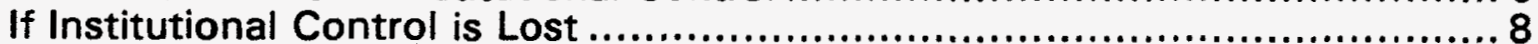

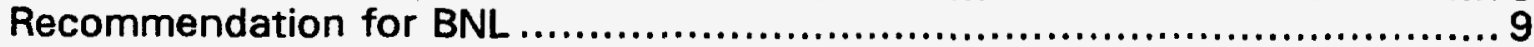

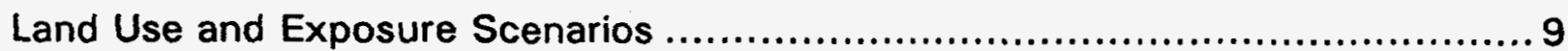

Suburban Residential Scenario ..................................................... 10

Commercial/Industrial Scenario ........................................................ 12

Recreational and Open Space Scenarios ...................................... 12

Criteria for Exposure Parameters .................................................. 13

Impacts to Groundwater ..................................................... 14

Net Benefit Analysis ............................................................. 16

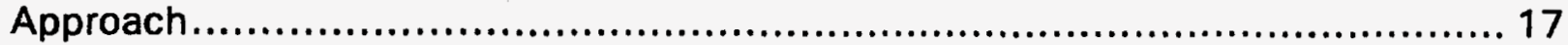

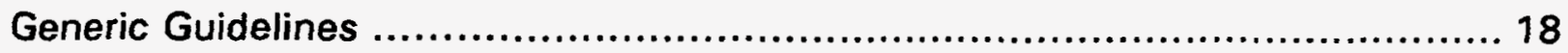

Implementation ................................................................. 23

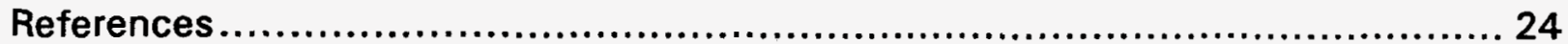

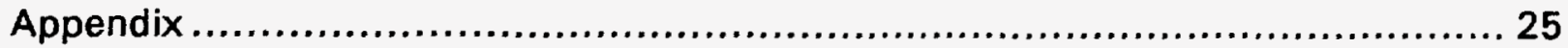

TABLES

1 Future Land Uses and Exposure Pathways at BNL ............................ 10

2 RESRAD Exposure Parameters for RME Analysis ............................. 11

3 Peak Concentrations in Water (pCi) Beneath Cleanup Site per $\mathrm{pCi} / \mathrm{g}$ in Soil (time of peak concentration in years);

Dose Conversion Factor (assumes 2 l/d; lifetime exposure);

USEPA MCLs and Associated Generic Guidelines 


\section{TABLES (cont.)}

4 Assuming Current Release of Site: Single-Radionuclide Preliminary Cleanup Guidelines $(p \mathrm{Ci} / \mathrm{f})$ for Four Land Uses at BNL Based on $15 \mathrm{mrem} / \mathrm{yr}$ Dose Limit and $75 \mathrm{mrem} / \mathrm{yr}$ for a Suburban Resident (guidelines less restrictive than the $75 \mathrm{mrem} / \mathrm{y}$ Residential Guidelines are Shaded)

5 Assuming Release of Site in 50 Years: Single-Radionuclide Preliminary Cleanup Guidelines $(\mathrm{pCi} / \mathrm{g}$ ) for Four Land Uses at BNL Based on $15 \mathrm{mrem} / \mathrm{yr}$ Dose Limit and $75 \mathrm{mrem} / \mathrm{yr}$ for a Suburban Resident (guidelines less restrictive than the $75 \mathrm{mrem} / \mathrm{y}$ residential guidelines are shaded)

6 Assuming Release of site in 100 Years: Single-Radionuclide Preliminary Cleanup Guidelines ( $\mathrm{pCi} / \mathrm{g}$ ) for Four Land Uses at BNL Based on Dose Limit and $75 \mathrm{mrem} / \mathrm{yr}$ for a Suburban Resident (guidelines less restrictive than the $75 \mathrm{mrem} / \mathrm{y}$ residential guidelines are shaded)

\section{FIGURES}

1 Planned Future Land Use (post-closure; from BNL; 1995)

2 Proposed Approach for Deriving Cleanup Guidelines for Radionuclides in Soils at BNL. 


\section{DISCLAMMER}

Portions of this document may be illegible in electronic image products. Images are produced from the best available original document. 


\section{INTRODUCTION}

Past activities at Brookhaven National Laboratory (BNL) resulted in soil and groundwater contamination. As a result, BNL was designated a Superfund site under the Comprehensive Environmental Response Compensation and Liability Act (CERCLA). BNL's Office of Environmental Restoration (OER) is overseeing environmental restoration activities at the Laboratory, carried out under an Interagency Agreement (IAG) with the United States Department of Energy (DOE), the United States Environmental Protection Agency (EPA) and the New York State Department of Environmental Conservation (NYSDEC).

With the exception of radium, there are no regulations to establish cleanup guidelines for radionuclides in soils at BNL. BNL must derive radionuclide soil cleanup guidelines for a number of Operable Units (OUs) and Areas of Concern (AOCs). These guidelines are required by DOE under a proposed regulation for radiation protection of public health and the environment (10 CFR Part 834) as well as to satisfy the requirements of CERCLA.

Site cleanups under Superfund must meet identified ARARS (Applicable or Relevant and Appropriate Regulations). When no ARARS are available, guidelines and nonpromulgated regulations are to be considered (TBC), and remedies are selected such that "the excess risk from any medium to an individual exposed over a lifetime generally falls within the range from $10^{-6}$ to $10^{-4}$ " (preamble to the National Contingency Plan (NCP), Federal Register 8686, March 8, 1990).

Application of the RESRAD (Residual Radioactive Material Guidelines, Yu et al., 1993) computer code constrained by a dose limit of $30 \mathrm{mrem} / \mathrm{yr}$ is a standard approach used at DOE sites to derive remedial guidelines for radionuclides in soil. In deriving guidelines for CERCLA cleanups, when faced with the absence of ARARS, a number of DOE sites have derived remedial guidelines by limiting risks to potential receptors (recreational users, trespassers, residents) to the range required by Superfund (generally $10^{-6}$ to $10^{-4}$ ) using United States Environmental Protection Agency (USEPA; EPA 1991) methods rather than the RESRAD code. 
The objective of this paper is to propose a standard approach to deriving riskbased cleanup guidelines for radionuclides in soil at BNL. A more detailed discussion of the proposed approach is available in a draft report prepared for the BNL Office of Environmental Restoration. Implementation of the approach is briefly discussed in this paper, and will be documented more fully in a formal report.

Several assumptions form the cornerstone of an approach to deriving cleanup guidelines:

1) the dose limit applied to control exposure and risk from residual radioactive material;

2) the land use scenarios used in the analysis of exposure, dose and risk to potential future receptors; and

3 ) the length of institutional control period assumed.

The approach described here also considers the costs and net benefits of remediation to the derived cleanup guidelines, and uses DOE's guidelines for applying the ALARA process to cleanup of the environment.

Recommended elements of the approach for deriving cleanup guidelines for radionuclides in soil at BNL are given below, and the overall approach is summarized. Implementation of the approach is underway, and more detailed documentation of the final guidelines used in selection of the final remedy is being prepared.

\section{BROOKHAVEN NATIONAL LABORATORY}

Brookhaven National Laboratory (BNL) is a DOE facility operated by Associated Universities. Inc. BNL is located on Long Island, New York, and consists of 21.3 $\mathrm{km}^{2}(2,130 \mathrm{ha})$. Most of the property is wooded, except for a developed area in the middle of the site of about $6.7 \mathrm{~km}^{2}$ (670 ha), and outlying facilities $\left(2.2 \mathrm{~km}^{2}\right.$; $222 \mathrm{ha}$ ) including a sewage treatment plant, research agricultural fields, housing and fire breaks. The general location of the buildings, roads and utilities are a legacy of the former Camp Upton.

Seventy-five percent of the site is in open space use. Most of the approximately 350 buildings and other structures are located in the centrally located developed area of the site which is currently designated for commercial/industrial use.

Potable water at the laboratory is drawn from deep wells. The water is monitored to ensure that it meets Federal and State drinking water standards, and is treated before use when necessary.

Approximately 30.25 ha (1.4\%) of the BNL property is contaminated with detectable concentrations of radionuclides in soil above background. These soils are located in several operable units (OUs). Radiologically contaminated 
soils will all be addressed under one Feasibility Study and final remedial action. Radiologically contaminated soils at BNL can be grouped into three categories:

\section{Hazardous Waste Management Facility (HWMF)}

The HWMF was the central receiving and storage facility for radioactive materials and waste at BNL for 50 years. Soils in the HWMF contain significant radiological contamination. Cesium-137 is the dominant radionuclide with a maximum reported concentration of $810,000 \mathrm{pCi} / \mathrm{g}$. Strontium- 90 is the second most prevalent radionuclide in the HWMF with a maximum soil concentration of $1300 \mathrm{pCi} / \mathrm{g}$. Approximately 35,000 cubic yards of soil at the HWMF may require remediation.

\section{Other Radiologically Contaminated Soils}

There are several smaller areas of low-level radiologically contaminated soils scattered around the facility. All of these are dominated by Cs-137 and Sr-90, and have smaller concentrations than those found at the HWMF Maximum Cs137 concentrations in these soils are less than $600 \mathrm{pCi} / \mathrm{g}$.

\section{Building 650}

Building 650 was a decontamination facility for the removal of radiation from clothing and heavy equipment. The mix of radioactively contaminated soils at Building 650 is different than that of other radiologically contaminated soils at BNL. In addition to elevated Cs-137 and Sr-90, these soils contain Eu-152, Eu154, Eu-155, Ra-226, Am-241, U-234, U-235, U-238, Pu-238, Pu-239, Pu-240, $\mathrm{Na}-22$, and $\mathrm{Co}-60$. Approximate maximum soil concentrations are: Cs-137 1800 $\mathrm{pCi} / \mathrm{g} ; \mathrm{Sr}-90147 \mathrm{pCi} / \mathrm{g}, \mathrm{Ra}-22663 \mathrm{pCi} / \mathrm{g}, \mathrm{Co}-6024 \mathrm{pCi} / \mathrm{g}, \mathrm{Pu}-239250 \mathrm{pCi} / \mathrm{g}$, Eu-152 $580 \mathrm{pCi} / \mathrm{g}$ and Eu-154 $350 \mathrm{pCi} / \mathrm{g}$.

\section{DOSE LIMIT FOR DERIVATION OF BNL CLEANUP GUIDELINES}

Except for radium (5 pCi/g; 40 CFR Part 192) no ARARS are available to guide cleanup of radionuclides in soil at BNL. EPA, DOE and USNRC (United States Nuclear Regulatory Commission) are planning to promulgate regulations for residual radioactive material in soil. Relevant proposed regulations and current New York State guidelines include:

- EPA Proposed Radiation Site Cleanup Regulation (40 CFR 196; EPA 1995); meant for release of sites, $15 \mathrm{mrem} / \mathrm{yr}$ above background levels that may be met by institutional controls; $75 \mathrm{mrem} / \mathrm{yr}$ to rural resident if controls fail. MCLs (maximum contaminant levels) in groundwater must be met if practicable. 
- DOE Proposed Regulation (10 CFR 834; Radiation Protection of the Public and the Environment); $100 \mathrm{mrem} / \mathrm{yr}$ from all sources except background, medical and occupational exposures. Exposure from a single site should be less than $30 \mathrm{mrem} / \mathrm{yr}$. Limits for radionuclides in soils must be derived using approved models.

- New York State Administrative Guideline (NYSDEC, 1993). The guideline suggests a dose limit of $10 \mathrm{mrem} / \mathrm{yr}$ above background, is meant for release of sites, and allows consideration of institutional controls.

Radionuclide concentrations (and the associated dose) that can be measured vary depending on the radionuclide and on measurement technique and equipment. For some radionuclides, it is difficult to distinguish the site-related levels from the background level.

Because of the large variation in background exposure across the United States and even within a single site, it will be difficult to document background levels at a specific site. Because of uncertainty in background levels, there can be difficulty in determining compliance with low dose limits.

USEPA considered minimum detectable concentrations (MDCs), background levels, and DOE analytical laboratory guidelines, and found that 14 radionuclides may be difficult to detect in soil at a concentration that corresponds to $15 \mathrm{mrem} / \mathrm{yr}$ under a rural residential exposure scenario (EPA, 1995). Those radionuclides that are of interest at BNL include Cs-137, K-40, Ra226, Ra-228, Sr-90, Th-230, Th-232, I-129, C-14 and Th-228. In most cases special analytical methods will be required to obtain the needed sensitivities for these isotopes.

Cleanup to low exposure rates from soil is not very cost-effective in terms of the number of deaths averted. In EPA's proposed Radiation Site Cleanup Standard (October 21, 1993; 58 FR 54474), the agency calculated the cost per death averted by remediating soils for all Federally owned sites with radionuclide soil contamination. Very few cancer deaths were averted, and the costs were high even for cleanup from the EPA baseline assumption of $100 \mathrm{mrem} / \mathrm{yr}$ to 75 $\mathrm{mrem} / \mathrm{yr}$. Cleanup to $15 \mathrm{mrem} / \mathrm{yr}$ was not at all cost effective (incremental costs from 25 to $15 \mathrm{mrem} / \mathrm{y} ; \$ 1000$ million/life saved). An average value currently used by Federal agencies is the U.S. is $\$ 5$ million/life saved (Baum, 1994). Values less than $15 \mathrm{mrem} / \mathrm{yr}$ resulted in additional deaths from exposure to remediation workers. Ecological risks, liabilities and property values were not considered in this analysis.

In its Proposed Radiation Site Cleanup Regulation, EPA chose $15 \mathrm{mrem} / \mathrm{yr}$ because it believed that the $15 \mathrm{mrem}$ standard provides an acceptable level of protection for the public, while standards less stringent would not provide an acceptable level of protection. Acceptable level was defined as consistent with the generally accepted range of $10^{-6}$ to $10^{-4}$. The $15 \mathrm{mrem} / \mathrm{yr}$ standard 
corresponds to an estimated lifetime incidence risk of cancer of about $3 \times 10^{-4}$ ( 30 year exposure, fatal cancer risk $2.3 \times 10^{-4}$ ).

EPA determined that "a cleanup level more stringent than 15 mrem would not be justifiable because below this level the incremental risks from remedial action begin to outweigh the incremental benefits, the technical difficulties of measuring more stringent cleanup levels increase, and the increased costs would not be reasonable compared to the small increase in benefits.(EPA 1995)". EPA did not choose $10 \mathrm{mrem} / \mathrm{yr}$ as the standard because cleaning to 10 rather than 15 $\mathrm{mrem} / \mathrm{yr}$ results in 2 additional deaths across all sites, and because the incremental cost was $\$ 1$ billion. EPA also determined that the $15 \mathrm{mrem} / \mathrm{yr}$ represents an acceptable fraction of the $100 \mathrm{mrem} / \mathrm{yr}$ recommendation of total public exposures from sources other than background, occupational and medical practices suggested by ICRP and NCRP (ICRP, 1991; NCRP, 1993).

The $15 \mathrm{mrem} / \mathrm{yr}$ limit is an extremely conservative limit that will be difficult to meet and does not consider the high costs and small benefits associated with meeting a dose limit so close to background. EPA has insisted that BNL derive guidelines based on a $15 \mathrm{mrem} / \mathrm{yr}$ dose limit, and New York State asked for a 10 mrem/yr limit.

In the proposed approach, when feasible, BNL will meet the proposed EPA dose limit of $15 \mathrm{mrem} / \mathrm{yr}$ assuming the institutional control associated with land uses other than rural residential use, and $75 \mathrm{mrem} / \mathrm{yr}$ for suburban residential use assuming failure of these institutional controls. When the $15 \mathrm{mrem} / \mathrm{yr}$ guideline is associated with unacceptable potential damage to ecological values, additional risks to the public or workers, or costs, BNL should base the cleanup guidelines on an alternate scenarios/dose limit combination that protects the public to at least $75 \mathrm{mrem} / \mathrm{yr}$. In this situation, alternatives that do not involve soil excavation (e.g. capping, fencing) will be considered.

The BNL assumptions differ from the proposed EPA rule in that the $75 \mathrm{mrem} / \mathrm{yr}$ dose limit associated with a loss of institutional control is assumed for a suburban resident rather than a rural resident because this is the most likely future residential land use near BNL.

Earlier guidelines derived for BNL have treated the $5 \mathrm{pCi} / \mathrm{g}$ limit for radium (UMTRCA 40 CFR Part 192; DOE Order 5400.5) as a separate limit not included in the overall dose limit for radionuclides in soil (BNL, 1996). This approach suggests including the dose from radium in the overall dose limit as that is clearly the intent of the proposed EPA regulation and there is no risk-based reason to treat radium separately. DOE may decide to use the $5 \mathrm{pCi} / \mathrm{g}$ standard for radium at BNL. 


\section{RESTRICTED USE AND INSTITUTIONAL CONTROL}

\section{The Myth of Unrestricted Use}

If clean-up were designed toward release of the BNL site for unrestricted use at some future date, proposed EPA guidance would suggest assuming a residentfarmer land use scenario (EPA, 1995). This is a family spending a substantial portion of time outdoors on the land, in contact with soil, who grow a substantial percentage of their food on the land, produce meat, poultry and milk, and whose drinking water comes from a private well tapping groundwater beneath the site. Their level of exposure is high in terms of time and pathways.

Even for an unrestricted use, this is not a realistic scenario for the BNL site. Farming is declining on Long Island, not growing. BNL is no longer in the country side; it is being rapidly surrounded by suburban growth with accompanying commercial and industrial development. A reasonable residential scenario would be suburban development, not a family farm. Meetings with stakeholders as part of the development of the future use plan (BNL, 1995) produced no suggestion of agricultural use. Advocates of residential land use proposed either institutional housing or low density residential zoning. It should be noted that low density residential zoning on Long Island does not indicate people who are subsisting on the land. Figure 1 shows the post-closure land use plan developed in cooperation with stakeholders (BNL, 1995).

But even suburban development may not be the most likely future were the site to be released. The BNL site is located in the Long Island Pine Barrens, a valuable natural resource. The core area of the Pine Barrens (comprising approximately $54 \%$ of the BNL site) is protected by the State of New York (Central Pine Barrens Joint Planning and Policy Commission, 1995). Much of the BNL site remains close to its natural state and BNL plans to continue to preserve this status as much as possible while carrying out its DOE mission (BNL, 1995). The BNL Future Land Use Plan reflects the public expectation that the bulk of the site will remain open space.

What will dictate the use of the land when the site is released? At this location, "unrestricted use" does not exist. The area is subject to the State Pine Barrens Plan, the Special Groundwater Protection Plan, the Long Island Comprehensive Wastewater Management Plan and local zoning controls. Wells may not be installed without a permit. Connection to a public water supply is mandatory for most new construction.

\section{Restricted Use and Institutional Control}

Restricted use includes actions ranging from retaining Federal control and putting up fences, to deed restrictions (prohibiting certain uses, e.g., agriculture or residential), deed notices (to alert all future owners of the presence of hazardous substances), or prohibiting use of wells. 


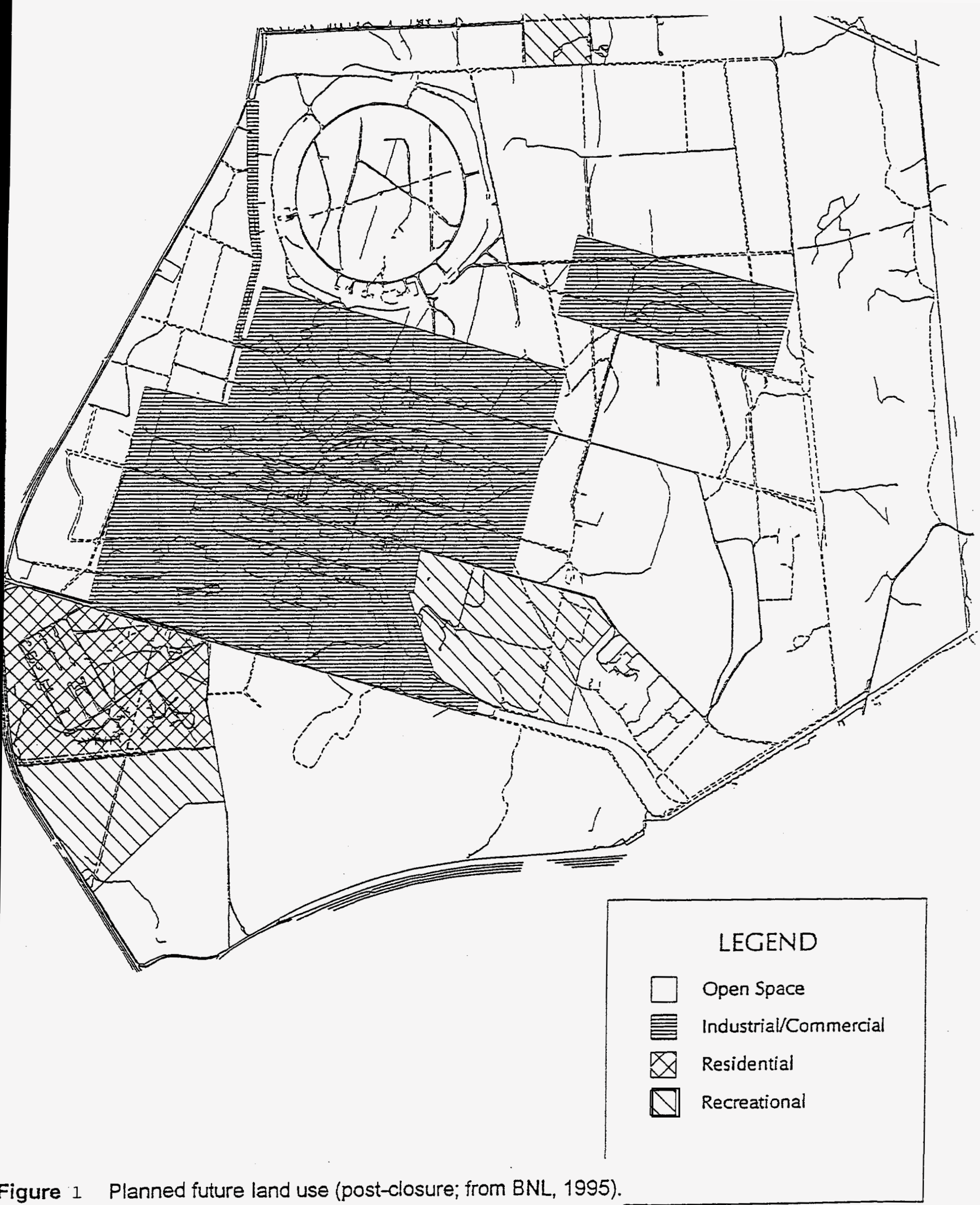

Figure 1 Planned future land use (post-closure; from BNL, 1995). 
EPA defines active control measures as "...all institutional controls and those engineering controls which control radiation dose or prevent exposure to members of the public, by methods other than physical removal "(EPA, 1995). Zoning presumably qualifies as an active control. EPA's draft regulation would require implementing entities to prepare a review every 5 years (EPA, 1995, p. 83) until radionuclide concentrations are reduced so that standards for rural residential use are not exceeded. EPA's proposed standards are aimed at clean-up of sites to be released from federal control.

The principal radionuclides contaminating soil at the BNL site are Cs-137 (halflife 30 years) and $\mathrm{Sr}-90$ (half-life 28 years). Maintaining institutional control of the site for $50-100$ years would result in substantial natural decay. If a specific soil clean-up level $(\mathrm{pCi} / \mathrm{g})$ were to be applied at a point $50-100$ years in the future, effective current cleanup standards would be 3- to 8-fold higher than if they were effective today. This could substantially reduce the cost of clean-up with no increase in exposure to the public, provided access to contaminated areas is controlled in the intervening period. There are no plans to close BNL. Moreover, DOE could make a commitment to retain control of the site even if laboratory operations were shut down. In terms of meeting criteria for release of the site, this strategy could be decided entirely on a cost basis. While the laboratory remains in operation, there would be incremental costs for monitoring, and costs for maintaining institutional control would be small. Were the laboratory to be closed at some point before site-release criteria were met, there would be additional costs for maintaining security of the site. DOE has already made this decision for OU IV -- preliminary guidelines were derived assuming 50 years of institutional control (BNL, 1996).

\section{If Institutional Control is Lost}

The institutional control that could be lost includes maintaining land use restrictions and prohibition of private wells after release of the site. These are maintained by local government. The BNL site is relatively small compared to other DOE sites and can easily be monitored. Moreover, state and local government and nongovernmental organizations take a special interest in the site because much of the site is in the core area of the Pine Barrens, a protected environment, and because the site also contains the headwaters of the Peconic River, a designated Scenic River. It is doubtful that institutional controls enforced by local governments would be seriously modified or breached at a site with such environmental and historic significance.

In their draft proposed radionuclide soil cleanup standards (EPA, 1995), EPA proposed a backup in case institutional controls failed. This was $75 \mathrm{mrem} / \mathrm{yr}$ in a resident farmer scenario. This would serve to keep public exposure within the $100 \mathrm{mrem} / \mathrm{y}$ limit of DOE Order 5400.5 and the recommendations of the ICRP and NCRP. EPA's proposal, however, was based on data from sites in more rural areas. There is no reasonable possibility that part of the BNL site would become a subsistence farm. The reasonable maximum $75 \mathrm{mrem} / \mathrm{y}$ backup scenario for establishing soil cleanup criteria is the suburban resident land use. 
The more restrictive of the suburban resident scenario at $75 \mathrm{mrem} / \mathrm{yr}$ or the expected land use at $15 \mathrm{mrem} / \mathrm{yr}$ should determine the cleanup criteria.

\section{Recommendation for BNL}

Soil cleanup guidelines can be developed to result in a $15 \mathrm{mrem} / \mathrm{yr}$ dose limit to receptors assuming the planned land use begins immediately after cleanup or at some time in the future when the site is released for other uses. Since DOE has no plan to curtail operations at BNL, some future time period for release of the site (e.g. 50 years) is a reasonable assumption. This paper presents generic soil cleanup guidelines assuming three time periods for release: current, 50 years in the future and 100 years in the future.

\section{LAND USE AND EXPOSURE SCENARIOS}

The scenarios characterize the future land-use pattern for the site and surrounding area. The land use that requires the most stringent cleanup criteria is generally considered to be the resident farmer. If the site is cleaned up such that this family is below the maximum tolerable risk level, it is generally considered acceptable for unrestricted use.

Based on current land uses near the BNL site, local controls on development and the BNL future land use plan (BNL, 1995), a residential farmer scenario is not a reasonable assumption to form the basis of remedial guidelines. The land use types described in the BNL future land use plan for the post-closure scenario (BNL, 1995) should be used to derive remedial guidelines for cleanups at specific site locations.

Future uses of the site will probably not include exposures to groundwater, because any future uses are expected to have access to public water. Ingestion of drinking water as an exposure pathway was included at the insistence of the regulatory agencies.

Four scenarios were developed for the BNL site: suburban residential; commercial/industrial; and two open space scenarios, one an undeveloped park and one a developed park. Most of the land on the BNL site is undeveloped. The BNL Future Land Use Plan (BNL, 1995), which was developed with extensive community involvement, determined that future land use at BNL would be primarily open space. Much of the open space on the BNL site is designated as part of the protected core area of the Long Island Pine barrens (Central Pine Barrens Joint Planning and Policy Commission, 1995).

EPA agreed that the likely future land use for the BNL site was open space. EPA insisted, however, that soil remediation guidelines be based on either residential or commercial/industrial land use. Their rationale for this was that, although the public was highly involved in the BNL Future Land Use Planning process, they did not realize at the time that one implication of an open space land use was that soil remediation requirements would be less stringent then residential or commercial. If the actual land use for most of the site is open 
space, use of residential or commercial/industrial assumptions in developing soil remediation guidelines will introduce a considerable additional margin of safety.

The land use scenarios developed for BNL are described below. Table 1 summarizes the exposure pathways assumed for each future land use.

Exposure parameters developed for these scenarios are given in Table 2 and documented in more detail in the Appendix.

Table 1. Future land uses and exposure pathways for BNL.

\begin{tabular}{|l|c|c|c|c|}
\hline Pathway & $\begin{array}{c}\text { Industriall } \\
\text { Commercial }\end{array}$ & $\begin{array}{c}\text { Suburban } \\
\text { Residential }\end{array}$ & $\begin{array}{c}\text { Undeveloped } \\
\text { Open Space }\end{array}$ & $\begin{array}{c}\text { Developed } \\
\text { Recreational } \\
\text { Space }\end{array}$ \\
\hline External gamma exposure & Yes & Yes & Yes & Yes \\
\hline Inhalation of dust & Yes & Yes & Yes & Yes \\
\hline Inhalation of radon & Yes & Yes & Yes & Yes \\
\hline Ingestion of plant foods & No & Yes & Yes & No \\
\hline Ingestion of meat & No & No & Yes & No \\
\hline Ingestion of milk & No & No & No & No \\
\hline Ingestion of fish & No & No & No & No \\
\hline Ingestion of soil & Yes & Yes & Yes & Yes \\
\hline Ingestion of water & Yes & Yes & Yes & Yes \\
\hline
\end{tabular}

\section{Suburban Residential Scenario}

BNL is in a suburban area that is becoming more densely populated. The BNL Future Land Use Plan (BNL, 1995) suggests that parts of the site currently used by BNL for residential, commercial (office space) or industrial (laboratory) use would likely continue in those uses were DOE to release the site. Suburban development is characterized by single family homes on $1 / 4$ to 2 acre lots (1/2 acre lots are assumed).

There are detailed plans for several thousand single and multiple family dwellings proposed within a $15 \mathrm{~km}$ area of the Laboratory, predominantly on the north, south and west boundaries. (BNL, 1995). Substantial residential development in areas close to BNL, and additional agricultural uses are not likely. 
Table 2. RESRAD Exposure Parameters for RME Analysis.

\begin{tabular}{|c|c|c|c|c|}
\hline RESRAD Parameters & $\begin{array}{l}\text { Commerciall } \\
\text { Industrial }\end{array}$ & $\begin{array}{l}\text { Suburban } \\
\text { Residential }\end{array}$ & $\begin{array}{l}\text { UnDeveloped } \\
\text { Open Space }\end{array}$ & $\begin{array}{l}\text { Developed } \\
\text { Recreational }\end{array}$ \\
\hline $\begin{array}{l}\text { Exposure Frequency (d/yr) } \\
\text { (not used as input value) }\end{array}$ & 250 & 350 & 300 & 40 \\
\hline $\begin{array}{l}\text { Daily inhalation rate }\left(\mathrm{m}^{3} / \mathrm{d} \text { ) }\right. \\
\text { (not used as input value) }\end{array}$ & 20 & 20 & 118 & 57.8 \\
\hline $\begin{array}{l}\text { Annual inhalation rate } \\
\left(\mathrm{m}^{3} / \mathrm{y}\right)\end{array}$ & 7,300 & 7,300 & 20,000 & 20,000 \\
\hline $\begin{array}{l}\text { Daily drinking rate (L/d) } \\
\text { (not used as input value) }\end{array}$ & 1 & 2 & 0 & 1 \\
\hline Annual drinking rate $(L / y)$ & 350 & 700 & 0 & 40 \\
\hline $\begin{array}{l}\text { Mass loading for inhalation } \\
\left(\mathrm{g} / \mathrm{m}^{3}\right)\end{array}$ & 0.0001 & 0.0001 & 0.0002 & 0.0001 \\
\hline $\begin{array}{l}\text { Fraction of time spent } \\
\text { indoors }\end{array}$ & 0.06 & 0.50 & 0 & 0 \\
\hline $\begin{array}{l}\text { Fraction of time spent } \\
\text { outdoors }\end{array}$ & 0.17 & 0.25 & 0.073 & 0.032 \\
\hline $\begin{array}{l}\text { Fruits, vegetables and grain } \\
\text { consumption (kg / yr) }\end{array}$ & 0 & 160 & 160 & 0 \\
\hline $\begin{array}{l}\text { Leafy vegetable } \\
\text { consumption }(\mathrm{kg} / \mathrm{yr})\end{array}$ & 0 & $\overline{14}$ & 0 & 0 \\
\hline Meat ingestion rate (kg/yr) & 0 & 0 & 63 & 0 \\
\hline Soil ingestion rate $(g / y r)$ & 36.5 & 43.8 & 36.5 & 65.7 \\
\hline $\begin{array}{l}\text { Livestock water fraction } \\
\text { contaminated }\end{array}$ & 0 & 0 & 0 & 0 \\
\hline $\begin{array}{l}\text { Contaminated fraction of } \\
\text { plants }\end{array}$ & 0 & 0.2 & 0.006 & 0 \\
\hline $\begin{array}{l}\text { Contaminated fraction of } \\
\text { meat }\end{array}$ & 0 & 0 & 0.14 & 0 \\
\hline $\begin{array}{l}\text { Livestock fodder intake for } \\
\text { meat }(\mathrm{kg} / \mathrm{d})\end{array}$ & 0 & 0 & 68 & 0 \\
\hline $\begin{array}{l}\text { Livestock water intake for } \\
\text { meat }(/ / d)\end{array}$ & 0 & 0 & 0 & 0 \\
\hline $\begin{array}{l}\text { Livestock intake for soil } \\
\text { (kg/d) }\end{array}$ & 0 & 0 & 0.01 & 0 \\
\hline $\begin{array}{l}\text { Mass loading for foliar } \\
\text { deposition }\left(\mathrm{g} / \mathrm{m}^{3}\right)\end{array}$ & 0 & 0.0001 & 0.0001 & 0.0001 \\
\hline
\end{tabular}


BNL is equipped with a water treatment plant and a water distribution system. Most of the undeveloped part of the BNL site, without water mains, is protected as part of the Pine Barrens Core Preservation Area. It is reasonable to assume that the existing water treatment plant may be continued in use by a future enterprise or the distribution system may be connected to the Suffolk County Water Authority (SCWA). The Suffolk County Department of Health Services (SCDHS) requires that new housing developments be connected to a municipal water supply. They also require that new individual houses within 150 feet of a main connect to the municipal source. The Suffolk County Water Authority (SCWA) has plans for additional water mains to the south and east of the Laboratory. Most future residential development in the surrounding area will be serviced by municipal water.

It is reasonable to expect that any drinking water provided on site will be from SCWA or will be treated to meet drinking water standards. None-the-less, because some homes in the area obtain water from private wells, at EPA's request, the Residential Scenario assumes that all water will come from on-site private wells without treatment.

\section{Commercial/Industrial Scenario}

This scenario characterizes the exposure of potential workers at commercial or industrial enterprises that may be established on the site in the future. There are detailed plans for two shopping centers, and a corporate park proposed within a $15 \mathrm{~km}$ area of the laboratory (BNL, 1995). Many current BNL activities are classed industrial or commercial and the post-closure scenario in the BNL Future Land Use Plan (BNL, 1995) suggests that the core developed area of the site might continue in commercial or industrial use. While the laboratory is in operation, an active safety and environmental protection organization monitors environmental contamination and assures the protection of laboratory employees and contractors. Once the site passes out of the control of the Federal government, this level of assurance can no longer be assumed. Commercial or industrial development in the central area of the site would most likely be consistent with the suburban character of the area, e.g., shopping center, office park or light industry.

It is reasonable to expect that any drinking water provided on site will be from SCWA or will be treated to meet drinking water standards. None-the-less, because some homes in the area obtain water from private wells, at EPA's request, the Commercial Scenario assumes that all water will come from on-site private wells without treatment.

\section{Recreational And Open Space Scenarios}

Much of the BNL site is designated as part of the protected core area of the Long Island Pine Barrens (Central Pine Barrens Joint Planning and Policy Commission, 1995). This provides a strong basis for assuming that the future use of much of the site will be undeveloped open space. Baseball and soccer 
fields already exist on site, and it is also possible that parts of the site may be developed for other recreational activities

Two different recreational scenarios are recommended. First is an undeveloped open space scenario and the second is a developed recreational park with ball fields and other facilities. In both cases it would be expected that only part of the BNL site would be devoted to the single land use.

The ingestion of meat included in the open space scenario represents hunting. BNL (1995b) indicates that there will be illegal hunting (poaching), but the new open space scenario assumes that hunting may be legal after the Federal government releases the site. For the developed recreational park scenario, however, it is assumed that development of the site will not only preclude hunting, but will greatly reduce the possibility of deer grazing on the land. The ingestion of produce in the open space scenario represents the gathering of mushrooms or berries.

\section{Criteria for Exposure Parameters}

EPA guidance provides that the exposures of the "reasonably maximally exposed (RME) individual" determine the cleanup requirements. It is not necessary to design the cleanup to protect a hypothetical maximally exposed individual, nor is it necessary to base the design on an extreme individual case.

Setting the value of a parameter that contributes to the estimate of the RME usually involves professional judgment. This judgment should be documented by providing the full possible range of the parameter, the average or midpoint, the value used as the RME, and the rationale for selecting that value.

Significant subpopulations with exposure patterns due to the kind of activities in which they engage or the amount of time they may spend on the site must be evaluated in determining the RME individual.

RMEs are estimated by pathway. If a subpopulation is exposed by more than one pathway, EPA (1989) indicates that "... the combination of exposures across pathways also must represent an RME." It may be necessary to consider trespassers or individuals involved in illegal acts (e.g., poaching game) if such individuals comprise a significant subgroup. Judgment can be used in determining whether a subpopulation should be evaluated. Further, the parameter values provided in EPA guidelines are to be regarded as general recommendations and can be changed based on site-specific information (EPA, 1989, p. 6-5).

Soil cleanup criteria are based on a reasonable maximum exposure (RME). These are exposures to which real people might be exposed, but the number of people so exposed is likely to be few.

For the purpose of evaluating net benefit, it is more appropriate to use the average exposure. The average exposure times the number of people exposed provides the total population exposure, from which the total effect can be calculated. 


\section{IMPACTS TO GROUNDWATER}

The aquifer underlying BNL has been designated a sole source aquifer; and assessing potential impacts to groundwater is an important part of the approach for deriving soil cleanup guidelines for BNL. Including the groundwater pathway in RESRAD does not guarantee that MCLs will be met -- only that the specified total dose limit will be met for all pathways. RESRAD can be used as a screening tool to assess worst-case potential impacts, but it is too simple and conservative for more accurate analyses. Groundwater models already in use at BNL can be used to estimate potential impacts to groundwater when a RESRAD calculation suggests a potential problem.

Table 3 gives worst-case groundwater concentrations predicted beneath the waste site using RESRAD for $1 \mathrm{pCi} / \mathrm{g}$ of radionuclides in soil. Maximum concentrations for different radionuclides occur at different time periods. Table 3 also shows the current MCLs (calculated for beta emitters from current ICRP models) and the generic BNL guideline that would result in the $\mathrm{MCL}$ in groundwater.

These concentrations are the maximum value reached over 1,000 years and are based on the waste site and geohydrological parameters used to derive the generic preliminary guidelines for BNL. OU and AOC specific predictions can be also be developed.

The proposed approach is to assess potential groundwater impacts in two steps:

- Use RESRAD to estimate the worst-case future concentration of radionuclides in groundwater beneath the waste site associated with a set of preliminary guidelines. Compare these concentrations to USEPA and NYS MCLs.

- If MCLs are exceeded in this analysis, perform a more detailed modeling analysis to estimate groundwater concentrations and doses for comparison to MCLs.

If this more accurate analysis suggests that MCLs may be exceeded, BNL should assess the net benefit associated with meeting MCLs, determine if meeting MCLs is practicable, and consider institutional controls that will eliminate the groundwater pathway. This decision should be made as part of the net benefit analysis performed on each set of preliminary guidelines. 
Table 3. Peak concentrations in water $(p C i / l)$ beneath cleanup site per $\mathrm{pCi} / \mathrm{g}$ in soil (time of peak concentration in years); dose conversion factor (assumes $2 \mathrm{l} / \mathrm{d}$; lifetime exposure); USEPA MCLs and associated generic guidelines.

\begin{tabular}{|c|c|c|c|c|c|}
\hline Radionuclide & $\begin{array}{c}\text { water:soil } \\
\text { ratio } \\
\text { (pCi/l per } \\
\text { pCi/g) }\end{array}$ & $\begin{array}{c}\text { time of } \\
\text { peak conc } \\
(y r)\end{array}$ & $\begin{array}{l}\text { pCi/l per mrem/yr } \\
\text { from proposed } \\
\text { regulations }\end{array}$ & $\begin{array}{c}\text { USEPA MCL }{ }^{3} \\
\text { (pCi/l) }\end{array}$ & $\begin{array}{c}\text { Generic } \\
\text { Guideline } \\
\text { Equivalent to } \\
\text { MCL (pCi/g) }\end{array}$ \\
\hline Americium-241 $(\alpha)$ & 0 & 210 & - & 15 & NC \\
\hline Cesium-137 ( $\beta)$ & 0 & - & 300 & 119 & $\mathrm{NC}$ \\
\hline Cobalt-60 ( $\beta)$ & 0 & - & 550 & 218 & NC \\
\hline Europium-152( $\beta)$ & 0 & - & 210 & 841 & NC \\
\hline Europium-154 ( $\beta$ ) & 0 & - & 143 & 573 & NC \\
\hline Europium-155 ( $\beta$ ) & 0 & - & 898 & 3590 & NC \\
\hline Plutonium-238 $(\alpha)$ & 0 & 560 & 1.79 & 15 & NC \\
\hline Plutonium-239 $(\alpha)$ & 0 & 725 & 16.2 & 15 & NC \\
\hline Plutonium-240 $(\alpha)$ & 0 & 700 & 16.2 & 15 & NC \\
\hline Radium-226 ( $\alpha)$ & $1.4 \times 10^{-4}$ & $1000^{4}$ & - & 5 & 7,143 \\
\hline Strontium-90 ( $\beta)$ & 6.8 & 70 & 10.5 & 8 & 1.2 \\
\hline Uranium-234 $(\alpha)$ & 8.2 & 540 & - & 15 & 1.8 \\
\hline Uranium-235 ( $\alpha$ ) & 8.2 & 540 & - & 15 & 1.8 \\
\hline Uranium-238 $(\alpha)$ & 4.1 & 849 & -- & 15 & 3.7 \\
\hline
\end{tabular}

${ }^{1}$ Concentration predicted by RESRAD directly under source.

2 Calculated for alpha emitters from Tables in 40 CFR 141, 142; Proposed National Primary Drinking Water Regulations (assumes 2l/d; lifetime exposure); based on latest ICRP models and parameter values for calculating dose (ICRP 60; ICRP, 1991).

${ }^{3}$ EPA-570/9-76-003; Current National Interim Primary Drinking Water Regulations: MCL for gross $\alpha$ emitters is $15 \mathrm{pCi} /$; for gross $\beta$ emitters $4 \mathrm{mrem} / \mathrm{y}$; for ${ }^{226} \mathrm{Ra}$ plus ${ }^{228} \mathrm{Ra}$ is $5 \mathrm{pCi} / /$. Concentrations of beta emitters associated with $4 \mathrm{mrem} / \mathrm{yr}$ calculated from new ICRP parameters as given in Proposed Standards (EPA, 1991).

${ }^{4}$ radium concentrations are small $\left(1.4 \times 10^{-4} \mathrm{pCi} / \mathrm{l}\right)$ but do not reach a peak in 1,000 years. NC - radionuclide not predicted to reach groundwater, minimum guideline not calculated. 


\section{NET BENEFIT ANALYSIS}

In addressing clean-up of contaminated areas, ICRP indicates that the decision criteria should be "do no harm", that is, the net effect of a clean-up activity should be positive (ICRP, 1991). Cleaning up contaminated areas can have negative impacts, for example:

- Remediation workers can incur radiation exposure and accidental injury.

- Transport of wastes to disposal sites causes traffic deaths and injuries, especially when large amounts of low-level wastes must be transported long distances.

- The natural ecology of an area is often disrupted. This is of particular concern where restricted access to a site has led to preservation of natural habitat for decades in areas where the surrounding area has experienced intensive development.

In its simplest form, net benefit analysis is simply a balancing of the positive and negative aspects of a decision. One difficulty frequently raised about net benefit analysis is that it requires all parts of the decision to be reduced to common (usually monetary) terms so the arithmetic can be done, i.e., the benefits and the costs can each be summed and the difference between them calculated.

Translating health risks or ecological values into monetary terms is controversial and reducing decisions to arithmetic is suspect. Transformation into monetary terms, however, is not necessary in cases where decisions are fairly straightfonward. In this case, for example, the following factors could be evaluated by the decision makers:

1) suitable future land use

2) clean-up levels for residual radioactive material

3) public health risk

4) worker health risk

5) preservation of wildlife habitat

6) cost of clean-up

What are the relationships? Increased clean-up leads to decreased public health risk, increased worker health risk, and increased destruction of habitat. Extensive clean-up may yield public health risks of $1 \times 10^{-5}$ life-time cancer, destruction of habitat, extensive worker exposure and very high costs. A lifetime risk guideline of $1 \times 10^{-3}$, however, might greatly reduce worker exposure, habitat destruction, and costs. The latter risk level is on the order of average exposures from radon gas. This is a range within which trade-offs might be made. Further flexibility can be achieved by land-use control. Residential use of land may require extensive clean-up to maintain acceptable risk, but using the land as a wildife preserve can maintain the same low risk because the duration and extent of human exposure is much reduced. 
These trade-offs may be controversial and difficult to agree on, but even when dealing with six parameters with different units and different values attached, as in the example, they are easily understood.

A calculation of the net benefit for each remedial alternative and its associated preliminary cleanup guidelines should be done as part of the FS phase of a CERCLA remedial action to help choose between alternatives. The approach suggested here assesses the net benefit of a remedial alternative, and factors into the decision on the final option the level of protectiveness (i.e. dose limit and land use assumptions) embedded in the remedial guidelines for residual radioactivity in soil.

Methods to estimate costs of alternative remedial actions are well established and are routinely performed as part of the Feasibility Study phase of a CERCLA remedial action. Risk to workers and the general public can be estimated using simple models and assumptions (EPA, 1995). Ecological values can be treated in a qualitative way, based on information presented in the Remedial Investigation Study for a specific AOC/OU and other data collected for the site.

These methods can be used to:

- determine if the $15 \mathrm{mrem} / \mathrm{yr}$ dose limit can be met without excessive costs, additional human health risks or destruction of important ecological values; and

- help choose between alternatives when the $15 \mathrm{mrem} / \mathrm{yr}$ dose limit is impracticable and alternatives that do not require excavation (or total excavations) are considered.

\section{APPROACH}

The proposed approach, outlined in Figure 2, uses the RESRAD model (Yu et al., 1993; Version 5.61) to calculate allowable residual concentrations of specific radionuclides in soil at BNL. Preliminary remediation guidelines are derived using a dose limit for the public of $15 \mathrm{mrem} / \mathrm{yr}$ above background together with scenario parameters for the land use planned for after site closure (BNL, 1995) or a $75 \mathrm{mrem} / \mathrm{yr}$ dose limit to a suburban resident, whichever is most restrictive. The potential impacts to groundwater associated with the preliminary guidelines are assessed using the simple groundwater model in RESRAD. More sophisticated, site specific models are used when the RESRAD analysis suggests that preliminary guidelines could cause MCLs to be exceeded.

When Cs-137 is the dominant radionuclide, guidelines can be based on the single radionuclide criteria derived for $\mathrm{Cs}-137$. Because $\mathrm{Sr}-90$ usually occurs with $\mathrm{Cs}$ in contaminated soils at BNL, potential groundwater impacts associated with residual $\mathrm{Sr}-90$ concentrations in soil must be assessed. When other radionuclides are present in significant concentrations, the guideline for each radionuclide must be based on the weighted sum of the radionuclides in the mixture as described in Yu et al. (1993). 
Remedial alternatives that depend on cleanup guidelines are then assessed in terms of the net benefit of cleanup to the preliminary guidelines. Costs of cleanup, potential ecological impacts and additional risks to the public and to remediation workers are compared to the number of cancers averted from performing the cleanup and to the costs associated with long term monitoring and maintenance of institutional controls.

If the costs and risks associated with the preliminary guidelines are reasonable or acceptable for a particular cleanup option that also meets the nine criteria defined by EPA (threshold, balancing and modifying criteria, National Contingency Plan; NCP, 40 CFR 300.430 ), they are accepted as final (along with the specific remedial option). After the cleanup process is complete, a formal process is used to document that a reasonable reduction of radiation exposures was achieved and that they are ALARA.

If the costs and risks for cleaning to the preliminary remedial guidelines are. unacceptable for the major remedial options under consideration, new guidelines are derived based on alternate combinations of dose limits, land use assumptions and remedies that do not involve excavation (i.e. capping, fencing and institutional controls). A net benefit analysis is done for these alternatives. The results of the net benefit analyses are used, in combination with the standard process used in a Feasibility Study to identify the best solution. An ALARA process is used during the design phase to cost-effectively reduce exposures to a reasonable and safe level below the final dose limit.

\section{GENERIC GUIDELINES}

Cleanup guidelines will vary across the BNL site because of differences in planned future land uses, different mixtures of radionuclides, differences in the size and nature of the source terms, and site specific geo-hydrological conditions. To reduce the confusion and complications associated with many different cleanup guidelines, generic preliminary cleanup guidelines were derived for BNL. These generic guidelines were derived using conservative boundary conditions and assumptions and represent average site geological and hydrological conditions. They will not always be appropriate because of site specific conditions (e.g. varying depths to groundwater), but do provide a consistent starting place from which more accurate site specific analyses can be performed if needed. Guidelines were developed assuming current release of the site, release of the site in 50 years, and release of the site in 100 years (Tables 4, 5 and 6). This approach recommends use of the guidelines for release of the site in 50 years, because the DOE currently has no plans to release the site.

The use of alternate land use scenarios and periods of institutional control have large effects on the soil cleanup guidelines. The period of institutional control assumed is especially important radioisotopes with relatively short half-lives (less than 30 years; Cs-137, Co-60, Eu-152, Eu-154, Eu-155, Sr-90). 
Figure 2 Proposed approach for deriving cleanup guidelines for radionuclides in soils at $B N L$.

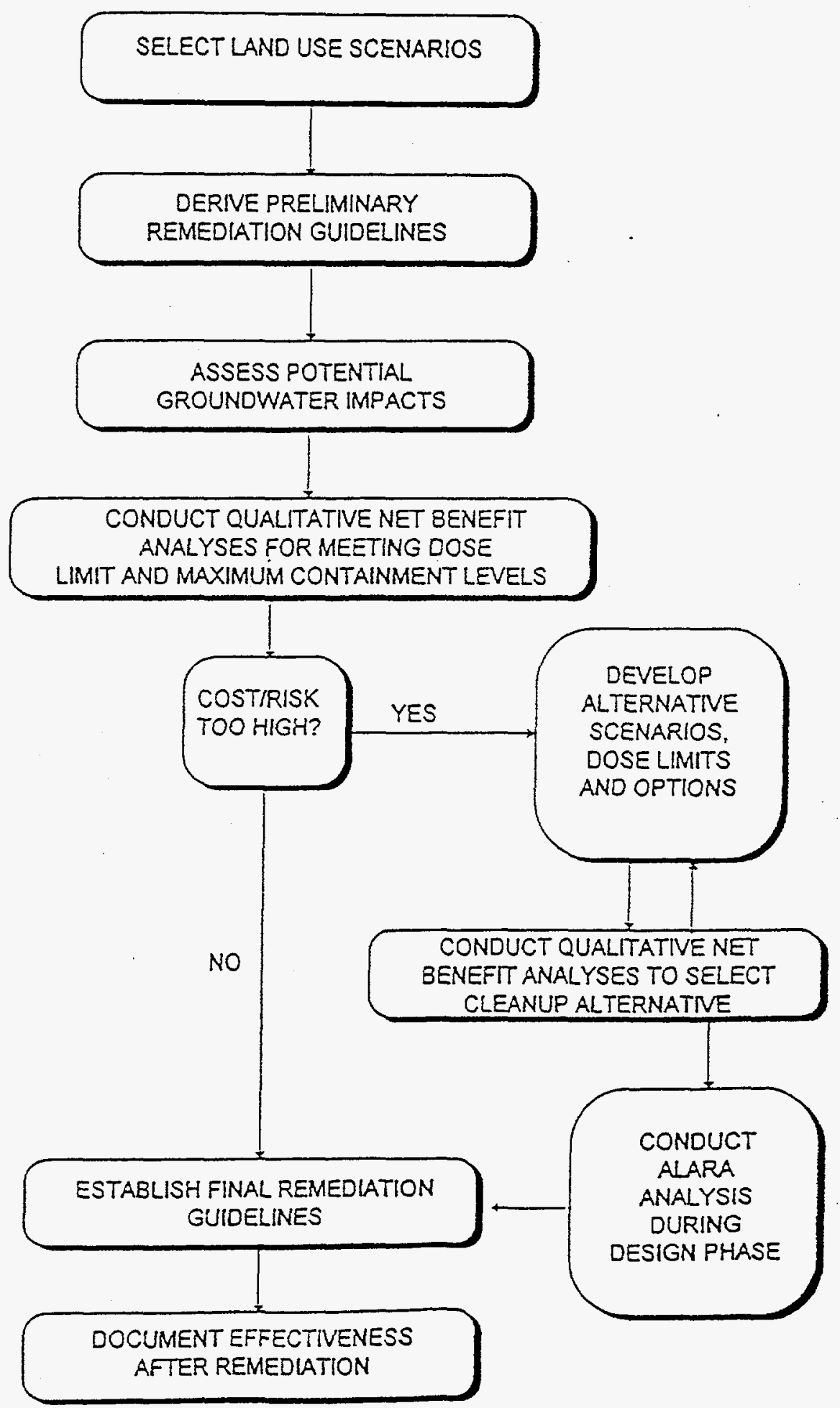


Table 4. Assuming current release of site: single-radionuclide preliminary cleanup guidelines ( $\mathrm{pCi} / \mathrm{g}$ ) for four land uses at BNL based on $15 \mathrm{mrem} / \mathrm{yr}$ dose limit and $75 \mathrm{mrem} / \mathrm{yr}$ for a suburban resident (guidelines less restrictive than the $75 \mathrm{mrem} / \mathrm{y}$ residential guidelines are shaded).

\begin{tabular}{|c|c|c|c|c|c|}
\hline Radionuclide & $\begin{array}{c}\text { Commercial/ } \\
\text { Industrial }\end{array}$ & $\begin{array}{l}\text { Suburban } \\
\text { Residential }\end{array}$ & $\begin{array}{l}\text { Developed } \\
\text { Open Space }\end{array}$ & $\begin{array}{l}\text { Developed } \\
\text { Recreational }\end{array}$ & $\begin{array}{c}\text { Suburban } \\
\text { Residential } \\
\text { (75 mrem/yr) }\end{array}$ \\
\hline Americium-241 & 150 & 36 & 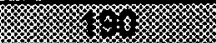 & Y & 180 \\
\hline Cesium-137 & 21 & 7 & $x$ & 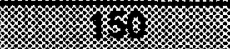 & 35 \\
\hline Cobalt-60 & $x$ & 1.5 & x & is & 7.5 \\
\hline Europium-152 & 10 & 3 & 4 & W & 15 \\
\hline Europium-154 & $\overline{9}$ & 3 & $3 \%$ & \% & 15 \\
\hline Europium-155 & 390 & 130 & 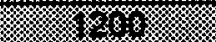 & 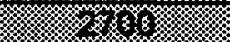 & 650 \\
\hline Plutonium-238 & 190 & 44 & 220 & 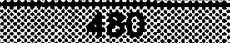 & 220 \\
\hline Plutonium-239 & 170 & 40 & 200 & 63 & 200 \\
\hline Plutonium-240 & 170 & 40 & 200 & 管 & 200 \\
\hline Radium-226* & 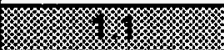 & 0.15 & 桨 & 桨 & 0.75 \\
\hline Strontium-90 & 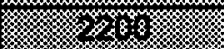 & 9 & $x$ & k & 45 \\
\hline Uranium-234 & 720 & 200 & 730 & 68 & 980 \\
\hline Uranium-235 & 84 & 28 & 要 & F & 140 \\
\hline Uranium-238 & 320 & 97 & 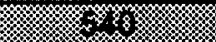 & 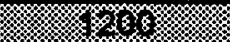 & 490 \\
\hline
\end{tabular}

* 5 pCi/g UMTRCA standard (40 CFR Part 192; DOE Order 5400.5) may apply 
Table 5. Assuming release of site in 50 years: single-radionuclide preliminary cleanup guidelines (pCi/g) for four land uses at BNL based on $15 \mathrm{mrem} / \mathrm{yr}$ dose limit and $75 \mathrm{mrem} / \mathrm{yr}$ for a suburban resident (guidelines less restrictive than the $75 \mathrm{mrem} / \mathrm{y}$ residential guidelines are shaded).

\begin{tabular}{|c|c|c|c|c|c|}
\hline Radionuclide & $\begin{array}{c}\text { Commercial } \\
\text { Industrial }\end{array}$ & \begin{tabular}{|c|} 
Suburban \\
Residential
\end{tabular} & $\begin{array}{l}\text { Developed } \\
\text { Open Space }\end{array}$ & $\begin{array}{c}\text { Developed } \\
\text { Recreational }\end{array}$ & $\begin{array}{c}\text { Suburban } \\
\text { Residential } \\
\text { (75 mrem/yr) }\end{array}$ \\
\hline Americium-241 & 160 & 39 & $x$ & $2 \%$ & 195 \\
\hline Cesium-137 & 70 & 23 & (6) & 3 & 115 \\
\hline Cobalt-60 & 3700 & 1300 & w & s. & 6300 \\
\hline Europium-152 & 140 & 48 & s. & 2 & 240 \\
\hline Europium-154 & 490 & 165 & (6) & 64 & 830 \\
\hline Europium-155 & $4.3 E 5$ & $1.4 \mathrm{E} 5$ & 6) & $x$ & $7.0 \mathrm{E} 5$ \\
\hline Plutonium-238 & 250 & 66 & 330 & (3) & 330 \\
\hline Plutonium-239 & 170 & 40 & 200 & (4) & 200 \\
\hline Plutonium-240 & 170 & $\overline{41}$ & 200 & (4) & 200 \\
\hline Radium-226* & 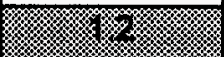 & 0.15 & 管 & 4 & 0.75 \\
\hline Strontium-90 & 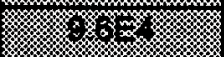 & 75 & (6) & s. & 380 \\
\hline Uranium-234 & 1200 & 350 & 1300 & \% & 1800 \\
\hline Uranium-235 & 130 & 49 & 3 & (3) & 250 \\
\hline Uranium-238 & 510 & 175 & $8 \%$ & (3) & 880 \\
\hline
\end{tabular}

* 5 pCi/g UMTRCA standard (40 CFR Part 192, DOE Order 5400.5) may apply 
Table 6. Assuming release of site in 100 years: single-radionuclide preliminary cleanup guidelines $(\mathrm{pCi} / \mathrm{g}$ ) for four land uses at $\mathrm{BNL}$ based on dose limit and 75 $\mathrm{mrem} / \mathrm{yr}$ for a suburban resident (guidelines less restrictive than the $75 \mathrm{mrem} / \mathrm{y}$ residential guidelines are shaded).

\begin{tabular}{|c|c|c|c|c|c|}
\hline Radionuclide & $\begin{array}{l}\text { Commercial } \\
\text { /ndustrial }\end{array}$ & $\begin{array}{c}\text { Suburban } \\
\text { Residential }\end{array}$ & $\begin{array}{l}\text { Developed } \\
\text { Open Space }\end{array}$ & $\begin{array}{c}\text { Developed } \\
\text { Recreational }\end{array}$ & $\begin{array}{l}\text { Suburban } \\
\text { Residential } \\
\text { (75 mrem/yr) }\end{array}$ \\
\hline Americium-241 & 180 & 43 & 220 & 4 & 220 \\
\hline Cesium-137 & 230 & 75 & F; & 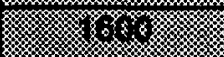 & 380 \\
\hline Cobalt-60 & $3.0 \mathrm{E6}$ & $1.1 \mathrm{E} 6$ & 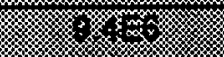 & 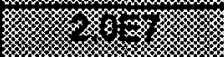 & 6E6 \\
\hline Europium-152 & 4 & 652 & 48 & 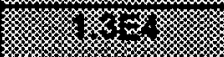 & 3300 \\
\hline Europium-154 & $2.6 \mathrm{E} 4$ & 8640 & (1) & 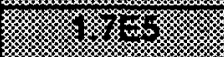 & $4.3 \mathrm{E} 4$ \\
\hline Europium-155 & 4.7E8 & $1.6 \mathrm{E} 8$ & \% & (x) & 8.0E8 \\
\hline Plutonium-238 & 420 & 100 & 500 & 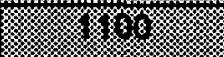 & 500 \\
\hline Plutonium-239 & 170 & 41 & 210 & 3 & 210 \\
\hline Plutonium-240 & 180 & 42 & 210 & s. & 210 \\
\hline Radium-226* & 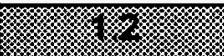 & 0.16 & 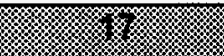 & Y & 0.8 \\
\hline Strontium-90 & 74 & 40 & w. & 2 & 200 \\
\hline Uranium-234 & 1800 & 600 & 4 & 4 媇 & 3000 \\
\hline Uranium-235 & 210 & 85 & $4 y$ & 38 & 420 \\
\hline Uranium-238 & 810 & 320 & (3) & 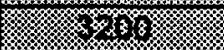 & 1600 \\
\hline
\end{tabular}

* 5 pCi/g UMTRCA standard (40 CFR Part 192, DOE Order 5400.5) may apply 
Earlier guidelines derived for $\mathrm{BNL}$ have treated the $5 \mathrm{pCi} / \mathrm{g}$ limit for radium (UMTRCA 40 CFR Part 192; DOE Order 5400.5) as a separate limit not included in the overall dose limit for radionuclides in soil (BNL, 1996). The approach described here suggests including the dose from radium in the overall dose limit as that is clearly the intent of the proposed EPA regulation and there is no riskbased reason for treat radium separately. Inclusion of radium in the $15 \mathrm{mrem} / \mathrm{y}$ dose limit at $B 650$, however, will require an expensive excavation of a large amount of soil with very little benefit. DOE may decide to use the $5 \mathrm{pCi} / \mathrm{g}$ standard for radium.

\section{IMPLEMENTATION}

The approach proposed here should be performed as part of the Feasibility Study (FS) phase of a CERCLA investigation when alternate remedies are identified and evaluated, and carried into the final cleanup stage when proposed ALARA assessments are performed and documented. The detailed net benefit analyses recommended here are meant for application in the detailed analysis of alternatives that occurs in the FS, but a more qualitative assessment could also be used in the initial screening of alternatives. A calculation of the net benefit for each remedial alternative should be done to help choose among alternatives.

An analysis of the net benefits associated with excavation of all contaminated soils above commercial/industrial guidelines at the HWMF found high costs and small benefits. BNL's current plan for remediation of radiologically contaminated soils is to:

1) Excavate only highly contaminated soils at HWMF. Cap area that exceeds the commercial/industrial cleanup level for Cs-137.

2) The level to determine excavation will be determined using failure analysis of the cap and assuming residential use after 50 years ( $75 \mathrm{mrem}$ dose limit).

3) Excavate Cs-137 and Sr-90 contaminated soils in other places onsite to residential guidelines. Consolidate excavated soils under cap at HWMF.

4) Excavate and dispose of soils at Building 650 (various radionuclides, with higher contamination levels than other soils) to residential cleanup guideline.

Recommended soil remediation guidelines at BNL were based on an exposure limit to future residents or workers of $15 \mathrm{mrem} / \mathrm{y}$ after 50-years of institutional control. For most soils on the BNL site contaminated with radionuclides, Cs-137 is the dominant radionuclide. Remediation guidelines have thus been based on this radionuclide. For the Building 650 sump in OU IV, however, a broad mix of radionuclides exists. Individual remediation guidelines were developed for each radionuclide. Remediation criteria will be based on the weighted sum of the radionuclides. 


\section{REFERENCES}

Baum, J., 1994, Value of Public Health and Safety Actions and Radiation Dose Avoided, prepared for the U.S. Nuclear Regulatory Commission by Brookhaven National Laboratory, Upton, NY, NUREG/CR-6212, BNLNUREG-52413.

BNL, 1995, Future Land Use Plan, Brookhaven National Laboratory, Upton, NY, BNL-62130.

BNL, 1996, Brookhaven National Laboratory, Operable Unit IV, Draft Record of Decision, January 19, 1996, Office of Environmental Restoration, Brookhaven National Laboratory; Brookhaven Area Office, U.S. Department of Energy, Upton, New York.

Central Pine Barrens Joint Planning and Policy Commission, 1995, Central Pine Barrens Comprehensive Land Use Plan, Volume 2: Existing Conditions, Central Pine Barrens Joint Planning Commission, Great River, New York

EPA, 1989, Risk Assessment Guidance for Superfund Vol. 1: Human Health Evaluation Manual (Part A), U.S. Environmental Protection Agency, Washington, DC, EPA 540/1-89/002.

EPA, 1991, Risk Assessment Guidance for Superfund (RAGS) Human Health Evaluation Manual, Part B - Development of Risk-Based Preliminary Remediation Guidelines. U.S. Environmental Protection Agency, Washington, DC. OSWER Directive 9285.7-01B.

EPA, 1995, Radiation Site Cleanup Regulation 40 CFR 196 (preliminary staff working draft) published in 58 FR 54474, U.S. Environmental Protection Agency, Washington, DC.

Federal Register, 1991, Environmental Protection Agency, National Primary Drinking Water Regulations; Radionuclides, 40 CFR Parts 141,142, 56:138:33050.

ICRP, 1991, "1990 Recommendations of the International Commission on Radiological Protection", Publication 60, Annals of the ICRP, 21:1-3, Pergamon Press, Oxford.

NCRP, 1993, Limitation of Exposure to lonizing Radiation, National Council on Radiation Protection and Measurements, NCRP Report No. 116, Bethesda, Md.

NYS, 1993. Cleanup Guidelines for Soils Contaminated with Radioactive Materials, Technical Administrative Guidance Memorandum No. 4003, New York State Department of Environmental Conservation.

Yu. et al., 1993. Manual for Implementing Residual Radioactive Material Guidelines Using RESRAD Version 5.0, Argonne National Laboratory, Environmental Assessment Division, ANL/EAD/LD-2. 


\section{APPENDIX}

\section{DOCUMENTATION RESRAD SCENARIO PARAMETERS FOR REASONABLE MAXIMUM EXPOSURE (RME) FOR FUTURE USERS OF BNL SITE}

Some of the parameters used in the RESRAD analysis are generic, e.g., conversion factors, plant to soil concentration ratios, and shielding factors. These are RESRAD default values documented in Yu et al. (1993a, b). In some cases these "defaults" were dependent on soil type (e.g., $K_{d}$ ) or climate (e.g., evapotranspiration). For $K_{d} s$, values for sand or sandy loam soil were chosen. In addition to being more appropriate for the BNL site than other options, values for sandy soil were lower than for other soil types. Climate-related parameters, e.g., humidity in air and evapotranspiration rates, were selected from maps in $\mathrm{Yu}$ et al. (1993b).

Some parameters, specific to the BNL site and applicable across the entire site, were based on site-specific information. These were mostly physical characteristics of the site, e.g., soil density, porosity, and hydraulic conductivity, and precipitation. These were based on measurements made on the BNL site. Distribution coefficients $\left(K_{d}\right)$ for strontium and uranium were also measured specifically in BNL soil. Parameters that vary by Operable Unit and Area of Concern include the area of the contaminated zone, the length parallel to aquifer flow, and depth to the water table, required to calculate the thickness of the uncontaminated unsaturated zone. These were derived from site maps, well data, and, in one case, estimated by the responsible project engineer.

Physical parameters specific to the BNL site are not given here. Detailed parameter documentation is available in a report prepared for the Office of Environmental Restoration at BNL. 


\section{BASIS FOR EXPOSURE PARAMETERS}

\section{Exposure Frequency (d/y)}

Note

This is not a RESRAD entry. It is used as the basis for estimating the percentage of time spent indoors and outdoors on site.

\section{Commercial/Industrial}

$250 \mathrm{~d} / \mathrm{y} \quad$ EPA reference value. Assumes worker is on site all days of the year except 104 weekend days and 10 additional days (holidays, vacation, sick or other absences).

\section{Residential (Suburban)}

$350 \mathrm{~d} / \mathrm{y} \quad$ Assume $15 \mathrm{~d} / \mathrm{y}$ are spent elsewhere (vacation, weekends away, etc.). This is the value from EPA RAGS, HHEM, Standard Default Exposure Factors (1991).

\section{Open Space (Undeveloped Park Visitor)}

$300 \mathrm{~d} / \mathrm{y} \quad$ A few adult joggers who live near the site may jog or walk on the site almost daily.

\section{Recreation (Developed Park Visitor)}

$40 \mathrm{~d} / \mathrm{y} \quad$ Assumes some adults may engage in sports on site for $40 \%$ of weekends.

\section{Inhalation Rate $\left(\mathrm{m}^{3} / \mathrm{y}\right)$}

\section{General Approach}

RESRAD operates on this parameter by applying the fraction of time indoors and outdoors, and with a further indoor shielding factor ( 0.8 for gamma rays, 0.4 for airborne particles), but doesn't allow for different inhalation rates indoors and outdoors. An appropriate weighted average value was calculated. Calculations are shown.

DeRosa and Levin (1978) provide inhalation rates by activity (rest, walk, run). The 95th percentile points of the inhalation rate appropriate to the scenario were used. These values are consistent with EPA (1990) Table 3A-2.

\section{Commercial/Industrial}

$7300 \mathrm{~m}^{3} / \mathrm{y}$ From EPA (1991). This is the total annual breathing rate at 20 $\mathrm{m}^{3} / \mathrm{d}$. This annual value is modified by the parameters fraction of time indoors and outdoors on site.

\section{Residential (Suburban)}

$7300 \mathrm{~m}^{3} / \mathrm{y}$ From EPA $(1991,1994)$. This is the total annual breathing rate at $20 \mathrm{~m}^{3} / \mathrm{d}$. This is the RESRAD default value. 


\section{Open Space (Undeveloped Park Visitor)}

$20,000 \mathrm{~m}^{3 /}$ Someone jogging on site 1 hour $/ \mathrm{d}, 300 \mathrm{~d} / \mathrm{y}$ is assumed. Based on informal questioning of current joggers at BNL, 1 hour per session is a RME; 300 $d / y$ is likely to be too high, but because of limited information, it is taken as an RME. Average inhalation rate while running is $4.9 \mathrm{~m}^{3} / \mathrm{h}$ (DeRosa and Levin, 1978). This level is described by EPA (1990) as considerably higher than crosscountry skiing or playing squash or handball. This yields:

$$
4.9 \mathrm{~m}^{3} / \mathrm{h} \times 24 \times 365=42,924 \mathrm{~m}^{3} / \mathrm{y}
$$

assuming one breathed at this rate continually for a year. RESRAD will apply the percentage of time outdoors to this factor to reduce it to the number of hours per year jogging on site, i.e., 300 hours. RESRAD, however, has a quality control check that prevents values above $20,000 \mathrm{~m}^{3} / \mathrm{y}$ from being entered. The entered value was thus set at $20,000 \mathrm{~m}^{3} / \mathrm{y}$ and a correction made in the fraction of time outdoors on site. The estimated fraction of time outdoors was 0.034 . This was modified:

$$
(42924 / 20000) * 0.034=0.073
$$

\section{Recreation (Developed Park Visitor)}

$20,000 \mathrm{~m}^{3} /$ Assume a weighted average of $25 \%$ running $\left(4.9 \mathrm{~m}^{3} / \mathrm{h}\right), 65 \%$ walking $\left(1.74 \mathrm{~m}^{3} / \mathrm{h}\right)$, and $10 \%$ resting $\left(0.6 \mathrm{~m}^{3} / \mathrm{h}\right)$ during a 4-hour period.

$$
0.25 \times 4.9+0.65 \times 1.74+0.1 \times 0.6=2.42 \mathrm{~m}^{3} / \mathrm{h}
$$

This is equivalent to $58 \mathrm{~m}^{3} / \mathrm{d}$ or $21,199 \mathrm{~m}^{3} / \mathrm{y}$ if this breathing rate were maintained continually. RESRAD will apply the fraction of time outdoors on site to obtain the amount breathed while actually jogging. There is no indoor exposure in this scenario.

RESRAD, however, has a quality control check that prevents values above $20,000 \mathrm{~m}^{3} / \mathrm{y}$ from being entered. The entered value was thus set at $20,000 \mathrm{~m}^{3} / \mathrm{y}$ and a correction made in the fraction of time outdoors on site. The estimated fraction of time outdoors was 0.018 . This was modified:

$$
(21199 / 20000) * 0.03=0.032 .
$$

\section{Drinking Water Rate (L/y)}

Commercial/Industrial

$350 \mathrm{~L} / \mathrm{y} \quad$ Based on applying EPA RME value of $1 \mathrm{~L} / \mathrm{d}$ for commercial/industry to $250 \mathrm{~d} / \mathrm{y}$ at work.

Residential (Suburban)

$700 \mathrm{~L} / \mathrm{y} \quad$ RME drinking water consumption in U.S. is $2 \mathrm{~L} / \mathrm{d}$ (Ershow and Cantor, 1989; EPA, 1991) multiplied by $350 \mathrm{~d} / \mathrm{y}$ in residence.

\section{Open Space (Undeveloped Park Visitor)}




\section{Recreation (Developed Park Visitor)}

$40 \mathrm{~L} / \mathrm{y} \quad$ Based an estimated RME value of $1 \mathrm{Ld}$ for 4 hours of recreational activity (assuming that water consumption is twice the hourly rate of industrial workers) and multiplying by $40 \mathrm{~d} / \mathrm{y}$.

\section{Mass loading for inhalation $\left(\mathrm{g} / \mathrm{m}^{3}\right)$}

\section{Commercial/Industrial}

$1 \times 10^{-4} \mathrm{~g} / \mathrm{m}^{3} \quad$ Average particle level in Brookhaven area is about $40 \mu \mathrm{g} / \mathrm{m}^{3}$ $=4 \times 10^{-5} \mathrm{~g} / \mathrm{m}^{3}$ of which less than $25 \%$ comes from entrainment of soil from site, given essentially all the site will have vegetation cover. While an industrial area might generate a higher particulate level, it would not be from contaminated soil. The higher value that is used $\left(1 \times 10^{-4} \mathrm{~g} / \mathrm{m}^{3}\right)$ appears to have been based on desert conditions at the Nevada Test Site, although it is also attributed to "... sustained periods of normal farmyard activities..." (ANL, 1993a). The use of the higher value was required by EPA and provides an order of magnitude factor of safety to this parameter.

Residential (Suburban)

$1 \times 10^{-4} \mathrm{~g} / \mathrm{m}^{3} \quad$ Average outdoor respirable particle level in BNL area (based on a study of 20 locations in Suffolk County) was $21.8 \pm 4.5 \mu \mathrm{g} / \mathrm{m}^{3}$ (Sheldon et al, 1989 as reported in EPA, 1995). The 95th percentile would be $30.8 \mu \mathrm{g} / \mathrm{m}^{3}=3 \times 10^{-5} \mathrm{~g} / \mathrm{m}$. Of this, however, only a fraction originates from soil. Values of that fraction are not available for Suffolk County, but estimates from a study in Portage, $\mathrm{WI}$, found $8.3 \%$ to $16.5 \%$ of respirable particles originated from soil. An earlier study in New York measured $8.3 \pm 4.1$ percent to $37 \pm 18$ percent (Kleinman et al, 1980). Taking the $16.5 \%$ value (second to highest) gives a RME soil mass loading value of $3 \times 10^{-5} \mathrm{~g} / \mathrm{m}^{3} \times 0.165=5 \times 10^{-6} \mathrm{~g} / \mathrm{m}^{3}$. This approximates the lower end of the range $9 \times 10^{-6}$ to $7.9 \times 10^{-5}$ suggested in ANL (1993). Most values of resuspension rates in the literature are from sites such as the Nevada Test Site and Hanford, where there is little vegetative cover and thus a high rate of wind resuspension. These rates are expressed in units of $\mathrm{g} / \mathrm{m}^{3}$ per $\mathrm{g} / \mathrm{m}^{2}$ which reduces to $\mathrm{m}^{-1}$. For example, these values often range as high as $10^{-5}$ or $10^{-4} \mathrm{~m}^{-1}$ compared to values measured in New York that range $10^{-9}$ to $10^{-8} \mathrm{~m}^{-1}$ (Sehmel, 1984). These differences also support the use of the low end of the ANL (1993) range. While a value of $5 \times 10^{-6} \mathrm{~g} / \mathrm{m}^{3}$ appears supportable, to assure a value consistent with the RME and to keep within the range given in ANL (1993), that value is doubled to $1 \times 10^{-5} \mathrm{~g} / \mathrm{m}^{3}$. The higher value used $\left(1 \times 10^{-5} \mathrm{~g} / \mathrm{m}^{4}\right)$ was required by EPA and provides an order of magnitude factor of safety to this parameter.

\section{Recreation (Developed Park Visitor)}

$2 \times 10^{-4} \mathrm{~g} / \mathrm{m}^{3} \quad$ The same as for open space scenario (above), except that the value is doubled to account for the increased activity resulting in an increase in the amount of airborne dust. 


\section{Open Space}

The Open Space scenario was identical to the Commercial/Industrial and Residential Scenarios above.

\section{Fraction of time spent indoors}

\section{General Approach}

This refers to the fraction of time spent indoors on-site. Exposure to direct radiation and contaminated wind-blown dust from outdoors is lower when indoors.

\section{Commercial Industrial}

0.06 Assumes workers are on site 250 days/year (EPA, 1991). That is, they work the equivalent of 50 weeks/year, 40 hours/week. Assumed workers spend $26 \%$ of their working time (about 2 hours) indoors and $74 \%$ (about 6 hours) outdoors on site. This assumes workers spend all their time other than 40 hours per week off the site. Since exposures are higher outdoors, the RME worker is one who spends most of his time outdoors. A typical worker might be expected to spend a much higher proportion of work time indoors. It should be noted that, where sources of radon gas are involved, the exposure rate indoors may be higher than the exposure rate outdoors. Indoor radon exposures, however, if present, are usually sufficiently high to overwhelm any occupancy fraction bias. EPA required use of this value for the RME scenario.

Residential (Suburban)

$0.50 \quad$ Residents spend 350 days/year on site. This assumes 15 days are spent elsewhere, e.g., vacation, weekends away, etc. (EPA, 1991). Of the 350 days in residence on site, $50 \%$ of time is assumed to be spent indoors at residence, $25 \%$ outdoors at residence, and $25 \%$ away from the site. Spending $50 \%$ of one's time indoors at home is equivalent to 84 hours/week. Most people spend a higher percentage of their time at home indoors. Since exposure rates are generally higher outdoors, the RME individual is assumed to spend a higher than average fraction of time at home outdoors. It should be noted that, where sources of radon gas are involved, the exposure rate indoors may be higher than the exposure rate outdoors. Indoor radon exposures, however, if present, are usually sufficiently high to overwhelm any occupancy fraction bias.

\section{Open Space (Undeveloped Park Visitor)}

$0 \quad$ All time spent outdoors.

Recreation (Developed Park Visitor)

$0 \quad$ All time spent outdoors. 


\section{Fraction of time spent outdoors}

\section{General Approach}

This refers to the fraction of time spent outdoors on-site. Exposure to direct radiation and contaminated wind-blown dust is higher outdoors than indoors.

\section{Commercial/Industrial}

0.17 Assumes workers are on site 250 days/year (EPA, 1991). That is, they work the equivalent of 50 weeks/year, 40 hours/week. The RME worker is assumed to spend $74 \%$ of work time outdoors and $25 \%$ indoors. This is because outdoor exposures are generally higher. Workers spend all their time other than $\mathbf{4 0}$ hours per week off the site.

Residential (Suburban)

0.25. Of the $\mathbf{3 5 0}$ days in residence on site, $50 \%$ of time assumed to be spent indoors at residence, $25 \%$ outdoors at residence, and $25 \%$ away from the site. $25 \%$ of the time outdoors is equivalent to 6 hours/day outdoors on weekend days and 2 hours/day outdoors on weekdays. Thus, the RME value represents a person who spends an unusual amount of time outdoors at home where the exposure to direct radiation and to contaminated dust is higher.

$0.073 \quad$ A jogger is assumed to spend 1 hour/d for $300 \mathrm{~d} / \mathrm{y}$ on site, all outdoors. The fraction of time outdoors on site is thus:

$$
300 / 8760=0.034
$$

The jogger spends fewer hours per year on site than was assumed for the visitor in BNL (1995b), but, based on the calculations shown above, even this estimate seems high. Moreover, the jogger has a higher breathing rate, so inhalation exposure is higher than in BNL (1995b).

RESRAD applies this fraction of time outdoors to the breathing rate in its calculation of the total volume of contaminated air inhaled per year jogging on site. RESRAD, however, has a quality control check that prevents breathing rate values above $20,000 \mathrm{~m}^{3} / \mathrm{y}$ from being entered. Since the breathing rate while jogging exceeds the limit, the entered value was set at $20,000 \mathrm{~m}^{3} / \mathrm{y}$ and a correction made in the fraction of time outdoors on site. The estimated fraction of time outdoors of 0.034 was modified as follows:

$$
(42924 / 20000) * 0.034=0.073 \text {. }
$$

For comparison, FEMP, in their final draft Remedial Investigation report (31 Oct. 1994) assumed adults spent 2 hours/day for 40 days/year, or 80 hours/year (fraction of time $=0.009$ ) in their undeveloped park scenario. Although we assume no camping would be allowed, one might consider how the selection of the dedicated jogger compares to a camper. Someone camping for two weeks on site would be there for 14 days $\times 24 \mathrm{~h} / \mathrm{d}=336$ hours/year, compared to the 300 hours/year for the jogger, who has a higher breathing rate. Thus, even if 
someone were to camp on the site, their exposure time would not be significantly different from the scenario assumptions.

\section{Recreation (Developed Park Visitor)}

0.032 The RME person is assumed to be a youth who engages in sports or related activities on site for 104 days/y, all outdoors, for an average of 4 hours/day. This is based on FEMP, final draft Remedial Investigation report (31 Oct. 1994). Youth (7 to 18) compose the highest exposure group. Since people are only youth for 10 years, however, while we consider a 30 year exposure duration, an age-averaged value is estimated. FEMP estimates children under 6 to visit the park 64 days/y for 4 hrs/day and adults for 40 days/y for 4 hours/day. The age-weighted average is:

$(64 \mathrm{~d} / \mathrm{y} \times 4 \mathrm{~h} / \mathrm{d} \times 6 \mathrm{y}+104 \mathrm{~d} / \mathrm{y} \times 4 \mathrm{~h} / \mathrm{d} \times 10 \mathrm{y}+40 \mathrm{~d} / \mathrm{y} \times 4 \mathrm{hr} / \mathrm{d} \times 14 \mathrm{y}) / 30 \mathrm{y}$

$$
=265 \text { hrs/year. }
$$

$265 \mathrm{hrs} / \mathrm{y} / 8760=0.03$ fraction of time outdoors on site.

RESRAD applies this fraction of time outdoors to the breathing rate in its calculation of the total volume of contaminated air inhaled per year jogging on site. RESRAD, however, has a quality control check that prevents breathing rate values above $20,000 \mathrm{~m}^{3} / \mathrm{y}$ from being entered. Since the breathing rate while jogging exceeds the limit, the entered value was set at $20,000 \mathrm{~m}^{3} / \mathrm{y}$ and a correction made in the fraction of time outdoors on site. The estimated fraction of time outdoors of 0.03 was modified as follows:

$$
(21199 / 20000) * 0.03=0.032 \text {. }
$$

Fruits, vegetables, grain consumption (total) $(\mathrm{kg} / \mathrm{y})$

\section{General Approach}

This parameter estimates the total amount of food consumed in this category. RESRAD then adjusts this factor by the fraction of food that is home grown. The RESRAD default value is $160 \mathrm{~kg} / \mathrm{y}$. Yang and Nelson (1984) estimated daily average food intake by category and subcategory for use in estimating radionuclide intake of individuals in the general population. They estimated total intake of produce (other than leafy vegetables) and grains at $162 \mathrm{~kg} / \mathrm{y}$, the RESRAD default.

\section{Commercial/Industrial}

$0.0 \mathrm{~kg} / \mathrm{y} \quad$ No produced grown in industrial or commercial area.

Residential (Suburban)

$160 \mathrm{~kg} / \mathrm{y}$ The RESRAD default (see also general approach, above). 


\section{Open Space (Undeveloped Park Visitor)}

$160 \mathrm{~kg} / \mathrm{y}$ The RESRAD default. The reason this category is turned on in the open space scenario arises from the possibility that visitors may collect mushrooms or berries.

\section{Recreation (Developed Park Visitor)}

0.0 No eatable material assumed to be grown in a recreational area.

\section{Leafy vegetable consumption (kg/y)}

\section{General Approach}

This parameter estimates the total consumption of leafy vegetables. RESRAD then adjusts this factor by the fraction of food that is home grown. The RESRAD default value is $14 \mathrm{~kg} / \mathrm{y}$. Yang and Nelson (1984) estimated daily average food intake by category and subcategory for use in estimating radionuclide intake of individuals in the general population. They estimated total intake of leafy vegetables at $14 \mathrm{~kg} / \mathrm{y}$, the RESRAD default.

\section{Commercial/Industrial}

$0.0 \quad$ No eatable material assumed to be grown in commercial or industrial areas.

Residential (Suburban)

$14 \mathrm{~kg} / \mathrm{y} \quad$ RESRAD default.

\section{Open Space (Undeveloped Park Visitor)}

$0.0 \quad$ No leafy vegetable consumption.

Recreation (Developed Park Visitor)

0.0 No eatable material assumed to be grown in recreational area.

\section{Contaminated Fraction of Plant Food}

Commercial/Industrial

$0.0 \mathrm{~kg} / \mathrm{y} \quad$ No produced grown in industrial or commercial area.

\section{Residential (Suburban)}

0.2 The bulk of food consumption from plants is from the category "fruits, vegetables, and grains" ( $160 \mathrm{~kg} / \mathrm{y}$ out of a total of $174 \mathrm{~kg} / \mathrm{y}$ ). Yang and Nelson (1984) estimated daily average food intake by category and subcategory for use in estimating radionuclide intake of individuals in the general population. Grains, however, make up $45 \%$ of the category "fruits, vegetables, and grains." Suburban families on Long Island do not grow grains. It is assumed in this suburban residential scenario that no grains are home grown. That reduces the total annual consumption from the RESRAD default of $160 \mathrm{~kg} / \mathrm{y}$ to $89 \mathrm{~kg} / \mathrm{y}$.

Citrus fruits also fall into this category. None are home grown in the BNL area. Based on a 3-day survey, EPA (1990) estimated $50 \mathrm{~kg} / \mathrm{y}$ of citrus fruits in this 
category. The overall estimate for the category "Protected Produce" in EPA (1990) in which citrus fruits fell, however, was 8.7 times higher than values from Yang and Nelson (1984) (also an EPA document). Applying the percentage fraction of citrus fruit to the Yang and Nelson number yields $16 \mathrm{~kg} / \mathrm{y}$ for citrus fruit. This leaves only $73 \mathrm{~kg} / \mathrm{y}$ in the fruit, produce and grain category that could possibly be grown in home gardens. Applying the EPA default value for the fraction of home grown vegetables $(0.4)$ and fruits $(0.3)$ to the vegetables that could be home grown on Long island, i.e., $14.3 \mathrm{~kg} / \mathrm{y}$ leafy vegetables, $31.4 \mathrm{~kg} / \mathrm{y}$ exposed produce (of which $69 \%$ is fruit and $31 \%$ vegetables) and $39 \mathrm{~kg} / \mathrm{y}$ protected produce, yields $25 \mathrm{~kg} / \mathrm{y}$ vegetables and $6.5 \mathrm{~kg} / \mathrm{y}$ fruit, or $20 \%$ of the $160 \mathrm{~kg} / \mathrm{y}$ total intake.

\section{Open Space (Undeveloped Park Visitor)}

0.006 Assumes possibility that visitor may collect mushrooms or berries. Since neither are plentiful in the area, assume RME individual collects $1 \mathrm{~kg} / \mathrm{y}$ out of total fruit, vegetable and grain category of $160 \mathrm{~kg} / \mathrm{y}$. The factor is also applied automatically to leafy vegetables category also; this might be associated with picking fresh salad greens.

Recreation (Developed Park Visitor)

0.0 No eatable material assumed to be grown of recreational area.

\section{Meat Consumption (kg/y)}

\section{General Approach}

It is assumed that because of the suburban nature of the area, no livestock will be kept on site and no hunting allowed in residential or commercial/industrial areas. Therefore, no meat will be produced. In the open space scenario, however, hunting may be allowed (or poachers may hunt illegally). In this scenario, an exposure pathway through eating wild game is included.

\section{Commercial/Industrial}

$0.0 \quad$ No meat production or hunting in commercial or industrial areas.

\section{Residential (Suburban)}

0.0 No meat production or hunting in residential areas.

\section{Open Space (Undeveloped Park Visitor)}

$63 \mathrm{~kg} / \mathrm{y}$ Total of beef, pork and other meat from all sources (RESRAD default). Yang and Nelson (1984) use $51.1 \mathrm{~kg} / \mathrm{y}$.

Recreation (Developed Park Visitor)

$0.0 \quad$ No hunting in recreational area.

Contaminated Fraction of Meat Consumption

Commercial/Industrial

0.0 No meat production or hunting in commercial or industrial areas. 


\section{Residential (Suburban)}

$0.0 \quad$ No meat production or hunting in residential areas.

\section{Open Space (Undeveloped Park Visitor)}

0.14 Since deer meat is the only contaminated meat consumed and, for the RME case, all deer meat consumed is assumed to come from the site, this is the fraction of deer meat to total meat. Deer meat consumption is assumed to be $8.85 \mathrm{~kg} / \mathrm{y}$. The RESRAD default value for total meat in the diet is $63.4 \mathrm{~kg} / \mathrm{y}$ (ANL, 1993a); the ratio of deer meat is thus $8.85 / 63.4=0.14$.

BNL (1995b) assumed game animals living on the decontaminated site constitute $10 \%$ of the meat diet of a recreational hunter. Radionuclide contaminated soil on the site, however, constitutes only $2 \%$ of the land area of the BNL site. The correction taken to account for this is in the "Livestock Fodder For Meat" parameter, below.

\section{Recreation (Developed Park Visitor)}

$0.0 \quad$ No hunting in recreational area.

\section{Soil ingestion rate $(\mathrm{g} / \mathrm{y})$}

\section{General Approach}

Both adults and children ingest small amounts of soil. Commercial exposures assume only adults, residential exposures assume children. Since people do not remain children for the 30 years of residence assumed, a weighted exposure over $\mathbf{3 0}$ years was calculated for the residential scenario.

\section{Commercial/Industrial}

$36.5 \mathrm{~g} / \mathrm{y} \quad$ Based on $100 \mathrm{mg} / \mathrm{d}$ (EPA, 1991, RME value for adults).

$$
100 \mathrm{~g} / \mathrm{d} \times 365 \mathrm{~d} / \mathrm{y}=36.5 \mathrm{~g} / \mathrm{y}
$$

RESRAD applies the fraction of time indoors and outdoors on site to this number.

\section{Residential (Suburban)}

$43.8 \mathrm{~g} / \mathrm{y} \quad$ Assuming a 30 year residence beginning at birth, the annual average RME exposure is calculated as 6 years at $200 \mathrm{mg} / \mathrm{d}$ and 24 years at $100 \mathrm{mg} / \mathrm{d}(\mathrm{EPA}, 1991)$ for 365 days per year.

$$
[(0.2 \mathrm{~g} / \mathrm{d} \times 6 \mathrm{y})+(0.1 \mathrm{~g} / \mathrm{d} \times 24 \mathrm{y})] \times 365 \mathrm{~d} / \mathrm{y} / 30 \mathrm{y}=43.8 \mathrm{~g} / \mathrm{y}
$$

RESRAD applies the fraction of time indoors and outdoors on site to this number.

\section{Open Space (Undeveloped Park Visitor)}

$36.5 \mathrm{~g} / \mathrm{y} \quad$ Based on $100 \mathrm{mg} / \mathrm{d}$ (EPA, 1991, RME value for adults).

$$
100 \mathrm{~g} / \mathrm{d} \times 365 \mathrm{~d} / \mathrm{y}=36.5 \mathrm{~g} / \mathrm{y}
$$


RESRAD applies the fraction of time indoors and outdoors on site to this number.

\section{Recreation (Developed Park Visitor)}

$65.7 \mathrm{~g} / \mathrm{y} \quad$ Assuming a 30 year residence beginning at birth, the annual average RME exposure is calculated as 6 years at $200 \mathrm{mg} / \mathrm{d}$ and 24 years at $100 \mathrm{mg} / \mathrm{d}(\mathrm{EPA}, 1991)$ for 365 days per year. The result is then increased by $50 \%$ to account for the greater possibility of contact with soil in sport.

$$
1.5 *[(0.2 \mathrm{~g} / \mathrm{d} \times 6 \mathrm{y})+(0.1 \mathrm{~g} / \mathrm{d} \times 24 \mathrm{y})] \times 365 \mathrm{~d} / \mathrm{y} / 30 \mathrm{y}=65.7 \mathrm{~g} / \mathrm{y}
$$

RESRAD applies the fraction of time indoors and outdoors on site to this number.

\section{Mass loading for foliar deposition $\left(\mathrm{g} / \mathrm{m}^{3}\right)$}

\section{Commercial/Industrial}

Not used since exposure through ingestion of plants is not applicable to the commercial/industrial scenario.

Residential (Suburban)

$1 \times 10^{-4} \mathrm{~g} / \mathrm{m}^{3}$ Average outdoor respirable particle level in BNL area (based on a study of 20 locations in Suffolk County) was $21.8 \pm 4.5 \mu \mathrm{g} / \mathrm{m}^{3}$ (Sheldon et al, 1989 as reported in EPA, 1995). The 95th percentile would be $30.8 \mu \mathrm{g} / \mathrm{m}^{3}=3 \mathrm{x}$ $10^{-5} \mathrm{~g} / \mathrm{m}$. Of this, however, only a fraction originates from soil. Values of that fraction are not available for Suffolk County, but estimates from a study in Portage, WI, found $8.3 \%$ to $16.5 \%$ of respirable particles originated from soil. An earlier study in New York measured $8.3 \pm 4.1$ percent to $37 \pm 18$ percent (Kleinman et al, 1980). Taking the $16.5 \%$ value (second to highest) gives a RME soil mass loading value of $3 \times 10^{-5} \mathrm{~g} / \mathrm{m}^{3} \times 0.165=5 \times 10^{-6} \mathrm{~g} / \mathrm{m}^{3}$. This approximates the lower end of the range $9 \times 10^{-6}$ to $7.9 \times 10^{-5}$ suggested in ANL (1993). Most values of resuspension rates in the literature are from sites such as the Nevada Test Site and Hanford, where there is little vegetative cover and thus a high rate of wind resuspension. These rates are expressed in units of $\mathrm{g} / \mathrm{m}^{3}$ per $\mathrm{g} / \mathrm{m}^{2}$ which reduces to $\mathrm{m}^{-1}$. For example, these values often range as high as $10^{-5}$ or $10^{-4} \mathrm{~m}^{-1}$ compared to values measured in New York that range $10^{-9}$ to $10^{-8} \mathrm{~m}^{-1}$ (Sehmel, 1984). These differences also support the use of the low end of the ANL (1993a) range. While a value of $5 \times 10^{-6} \mathrm{~g} / \mathrm{m}^{3}$ appears supportable, to assure a value consistent with the RME and to keep within the range given in ANL (1993a), that value is doubled to $1 \times 10^{-5} \mathrm{~g} / \mathrm{m}^{3}$. The higher value used $\left(1 \times 10^{-4} \mathrm{~g} / \mathrm{m}^{4}\right)$ was required by EPA and provides an order of magnitude factor of safety to this parameter.

\section{Open Space (Undeveloped Park Visitor)}

$1 \times 10^{-4} \mathrm{~g} / \mathrm{m}^{3} \quad$ Same as in the Residential Scenario, above. In addition, note that in this scenario, essentially all the site will have vegetation cover. 


\section{Recreation (Developed Park Visitor)}

$1 \times 10^{-4} \mathrm{~g} / \mathrm{m}^{3} \quad$ Average particle level about $40 \mu \mathrm{g} / \mathrm{m}^{3}=1 \times 10^{-5} \mathrm{~g} / \mathrm{m}^{3}$ of which less than $25 \%$ comes from entrainment of soil from site, given essentially all the site will have vegetation cover. This could be slightly higher to be consistent with estimate of soil inhalation, but has no effect since no vegetation is consumed from the site.

\section{Livestock Fodder (applied to deer) (kg/d)}

\section{General Approach}

This applies only to the open space scenario since other scenarios do not permit hunting or raising of livestock.

\section{Open Space Scenario}

68. $\mathrm{kg} / \mathrm{d} \quad$ Radionuclide contaminated soil on the site constitutes less than $2 \%$ of the land area of the BNL site. It initially seemed reasonable to assume that radioactively contaminated areas are randomly selected in the grazing area. Thus it was assumed initially that contamination in the deer meat should be only $2 \%$ of that which would be expected were the deer to graze only on radioactively contaminated areas. Since the RESRAD default intake is 68 $\mathrm{kg} / \mathrm{d}$, correcting for the $2 \%$ factor yields $68 \mathrm{~kg} / \mathrm{d} \times 0.02=1.36$. Much of the area contaminated with radionuclides is landscaping soil containing about $300 \mathrm{pCi} / \mathrm{g}$ Cs-137. This area is covered with grass and is attractive to deer. Although deer clearly do much of their grazing on non-contaminated soils, the appropriate values should be above $1.36 \mathrm{~kg} / \mathrm{d}$. EPA required that the full $68 \mathrm{~kg} / \mathrm{d}$ be used. Note that the RESRAD default value of $68 \mathrm{~kg} /$ day applies to cattle, not deer. The difference in mass per day is not relevant, since it is normalized to the amount of meat consumed. There is a potential difference, however, in the uptake coefficient due to differences in how the animals feed or how they metabolize the cesium.

\section{Livestock (deer) Intake of Soil (kg/d)}

\section{General Approach}

This applies only to the open space scenario since other scenarios do not permit hunting.

$0.01 \mathrm{~kg} / \mathrm{d} \quad$ The RESRAD default value for cattle is $0.5 \mathrm{~kg} / \mathrm{d}$. In this case, there are no cattle; this part of RESRAD is used to estimate the intake of deer. The fraction of the site for which soil is contaminated with radionuclides is $2 \%$. The intake rate of $0.5 \mathrm{~kg} / \mathrm{d}$ was thus reduced to $2 \%$ of that value to represent the intake of contaminated plant food by deer. Further improvements can be made to the estimate of dose through this pathway. For example, deer eat considerably less soil than cattle. See also entry above on livestock fodder. 


\section{References}

BNL, 1995a, Future Land Use Plan (BNL-62130), Brookhaven National Laboratory, Upton, NY.

BNL, 1995b, Brookhaven National Laboratory Draft Remedial Investigation/Risk Assessment Report, Operable Unit I/IV, Vol 2B, Baseline Radiological Risk Assessment, September 21, prepared by CDM Federal Programs Corp, New York, New York.

Central Pine barrens Joint Planning and Policy Commission. 1995. Central Pine Barrens Comprehensive Land Use Plan, Great River, NY.

DeRosa M.I., Levin, R., 1978, Simulation of Man's Respiratory and Metabolic Functions by the Automated Breathing Metabolic Simulator (IC 8766), U.S. Department of Interior, Bureau of Mines, Washington, D.C.

EPA. 1990. Exposure Factors Handbook (EPA600/8-89/043), Exposure Assessment Group, Office of Health and Environmental Assessment, United States Environmental Protection Agency, Washington, D.C.

EPA, 1991, Risk Assessment Guidance for Superfund - Volume I Human Health Evaluation Manual (Part B Development of Risk-Based Preliminary Remediation Guidelines) Interim Final,. United States Environmental Protection Agency. (285.7-01B). October 1991.

EPA, 1994. EPA Radiation Site Cleanup Regulations Technical Support Document, Volume I, Methods for The Development of Radionuclide Soil Cleanup Levels, United States Environmental Protection Agency, Office of Radiation and Indoor Air, Washington, D.C.

Ershow, A. G. and K.P. Canter. 1989. Total water and tap water intake in the United States: population-based estimates of quantities and sources. Life Sciences Research Office, Federation of American Societies for Experimental Biology.

ANL, 1993a, Manual for Implementing Residual Radioactive Material Guidelines Using RESRAD, Version 5.0. Argonne National Laboratory, Environmental Assessment Division, ANL/EAD/LD-2. September 1993.

Sheldon, L.S. et al. 1989. An investigation of infiltration and indoor air quality: final report. New York State Energy Research and Development Authority, Albany, NY.

Kleinman, M.T. et al. 1980. "Identifying and estimating the relative importance of sources of airborne particulates", Environmental Science and Technology 14: $62-65$. 
Sehmel, G.A. 1984. "Deposition and resuspension", Chapter 12 in D. R. Anderson (ed), Atmospheric Science and Power Production, Office of Scientific and Technical Information, U.S. Department of Energy, Washington, DC.

Yang, Y-Y and C.B. Nelson. 1984. An estimation of the daily average food intake by age and sex for use in assessing the radionuclide intake of individuals in the general population, Office of Radiation Programs, U.S. Environmental Protection Agency, Washington, DC. 